\title{
Increase in Anoxia in Lake Victoria and Its Effects on the Fishery
}

\author{
Murithi Njiru ${ }^{1}$, Chrisphine Nyamweya², John Gichuki², \\ Rose Mugidde $^{3}$, Oliva Mkumbo ${ }^{4}$ and Frans Witte ${ }^{5}$ \\ ${ }^{1}$ Department of Fisheries and Aquatic Sciences, Moi University, Eldoret, \\ ${ }^{2}$ Kenya Marine and Fisheries Research Institute, Kisumu, Kenya \\ ${ }^{3}$ COWI, Uganda Ltd, Plot No. 3, Portal Avenue, Kampala, \\ ${ }^{4}$ Lake Victoria Fisheries Organisation (LVFO), Jinja, \\ ${ }^{5}$ Institute of Biology Leiden, Leiden University, Leiden, \\ 1,2 Kenya \\ 3,4 Uganda \\ ${ }^{5}$ Netherlands
}

\section{Introduction}

Lake Victoria is the second largest freshwater lake in the world and the largest in the tropics (Crul, 1995). It is found in East Africa, within $0^{\circ} 20^{\prime} \mathrm{N}$ to $3^{\circ} 00^{\prime} \mathrm{S}$ and $31^{\circ} 39^{\prime} \mathrm{E}$ to $34^{\circ} 53^{\prime} \mathrm{E}$ at an altitude of $1134 \mathrm{~m}$. It has a surface area of about $68,800 \mathrm{~km}^{2}$ and a maximum depth of about $70 \mathrm{~m}$. The lake is shared by Tanzania (51\%), Uganda (43\%), Kenya (6\%), with a drainage basin of about $195000 \mathrm{~km}^{2}$ which includes the neighbouring states of Rwanda and Burundi. Lake Victoria originated less than 1 million years ago and may have been dry for several millennia until about 14,000 years ago (Stager \& Johnson, 2007). The lake and its numerous satellite lakes were originally dominated by a rich fish fauna, comprising several hundred species of cichlids (Kaufman et al., 1997).

Until the 1960s, the tilapiine species Oreochromis esculentus (Graham) and Oreochromis variabilis (Boulenger) were the most important commercial species. Other important species included Protopterus aethiopicus Heckel, Bagrus docmak (Forsskål), Clarias gariepinus (Burchell), various Barbus species, mormyrids and Schilbe intermedius Rüppell. Labeo victorianus Boulenger formed the most important commercial species in the affluent rivers of the lake basin. Haplochromine cichlids and a native pelagic cyprinid, Rastrineobola argentea (Pellegrin), were abundant, but were not originally exploited on a large scale because of their small size (Kudhogania \& Cordone, 1974; Ogutu-Ohwayo, 1990). In the late 1950s and early 1960s, the predatory Nile perch Lates niloticus (L) and four tilapiine species, Nile tilapia, Oreochromis niloticus (L), Oreochromis leucostictus (Trewavas), Tilapia zillii (Gervais) and Tilapia rendalii Boulenger, were introduced into the Lake Victoria basin to increase depleted commercial fisheries (Ogutu-Ohwayo, 1990, 1994). Thereafter, the fish community of lake with over $50 \%$ of native fish species (> 99\% endemic haplochromines cichlids) disappeared (Ogutu-Ohwayo, 1990; Witte et al., 1992a). Decline in haplochromines was attributed mainly to the predatory Nile perch (Ogutu-Ohwayo, 
1990). Nile tilapia which was better competitor for resources hybridized and displaced the indigenous oreochormine group. The once multispecies fishery was converted to three species, viz Nile perch, Nile tilapia and $R$. argentea, changing drastically the food web. However, the introduction of Nile perch transformed the fisheries from a locally based artisanal fishery to an international capital investment industry. The fisheries produces an annual income of approximately \$US 600 million, providing employment opportunities for over 3 million people (Njiru et al., 2005).

For the past few decades, Lake Victoria basin has undergone environmental degradation leading to increased nutrients inputs into the lake leading to eutrophication, (Hecky et al., 1994). Increased eutrophication has led to increased algal blooms and deoxygenation in the deeper waters (Talling, 1966, Hecky et al., 1994). Hypoxia which occurred only in deep waters in the 1960s (Talling, 1966), is now more frequent and is spreading into shallow waters (Hecky et al., 1994, Mugidde et al., 2005). Deoxygenation, intense fishing and predation by Nile perch contributed to the demise of many native species (Ogutu-Ohwayo 1990, 1994; Kaufman \& Ochumba, 1993). This chapter explores the impact of hypoxia on the fishery of Lake Victoria.

\section{Fish and dissolved oxygen}

Oxygen is necessary to sustain life of fishes dependent on aerobic respiration (Diaz \& Breitburg, 2009). Availability of dissolved oxygen (DO) is one abiotic factor that can limit habitat quality, distribution, growth, reproduction, and survival of fishes (Kramer, 1987). Though all fishes require oxygen for survival, the physical properties of water (high viscosity, low oxygen content at saturation) makes its uptake challenging for fishes even at high DO levels (Kramer, 1987). When the supply of oxygen is cut off or consumption exceeds resupply, DO concentration can decline below levels required by most animal life. The condition of low DO is known as hypoxia while water devoid of oxygen is referred to as anoxic. Hypoxia and anoxia differ quantitatively in the availability of oxygen, as well as qualitatively in the presence of toxic compounds such as hydrogen sulfide. Hypoxia can be described in several forms (Farrell \& Richards, 2009; Diaz \& Breitburg, 2009). Aquatic hypoxia can be defined as dissolved oxygen concentrations below 5-6 $\mathrm{mg} \mathrm{l}^{-1}$ in freshwater, 2-3 $\mathrm{mg} \mathrm{l}^{-1}$ in marine and estuarine environments.

Hypoxia is a natural component of many freshwater habitats. Hypoxic conditions can be due to natural causes such as algal respiration, seasonal flooding, stratification, and anthropogenic causes. Low dissolved oxygen environments vary in temporal frequency, seasonality, and persistence (Farrell \& Richards, 2009; Diaz \& Breitburg, 2009; Wetzel, 2001). Hypoxia occurs naturally in habitats characterized by low mixing or light limited, heavily vegetated swamps and backwaters that circulate poorly, stratify, and have large loads of terrestrial organic matter (Kramer, 1987; Chapman et al., 1999). Levels of hypoxia are mainly determined by primary productivity, depth, and temperature of the aquatic body (Wetzel, 2001).

Hypoxia is physiologically stressful for fish, shellfish, and invertebrates with prolonged exposure to anoxia being fatal to most aquatic fauna (Diaz \& Breitburg, 2009; Chapman \& McKenzie, 2009). Hypoxia exposure can prompt both lethal and sublethal effects in fishes, 
leading to reduced feeding, reproductive, growth, metabolism, and slower reaction time. These effects vary across fish species (Chapman \& McKenzie, 2009), but also depend on the frequency, intensity, and duration of the hypoxic events (Diaz \& Breitburg, 2009). Fishes can compensate for hypoxic conditions by decreasing their need for oxygen, increasing the amount of oxygen available, or combining both strategies (Reardon \& Chapman, 2010).

\section{Hypoxia in Lake Victoria}

Hypoxic (and anoxic) environments in aquatic systems have existed through geological time (Chapman \& McKenzie, 2009). However, environmental degradation and global climate changes is increasing the occurrence of hypoxia. Increase in inputs from municipal wastes and agricultural runoffs have accelerated eutrophication of water bodies. This has altered the balance of aquatic ecosystem productivity and metabolic activities of bacteria leading to hypoxic conditions. In, Lake Victoria, hypoxia was first recorded in the late 1920s (Worthington, 1930). Fossil evidence indicated that the hypoxia in the lake could be attributed to continued increase in nutrients inputs, and altered food-web following the boom of predaceous Nile perch in the 1980s (Verschuren et al., 2002). Palaeolimnological data showed an increase in phytoplankton production from 1930s, paralleling humanpopulation growth and agricultural activity in the lake basin (Verschuren et al., 2002). Using evidence from changes in the Procladius/ Chironomus ratio of fossil midge faunas, Verschuren et al., (2002) reported that the deep-water oxygen regime of Lake Victoria started to deteriorate in the early 1960s. Seasonally persistent deep-water anoxia appeared to have reached its current level by the late 1970s. These fossil data agree with historical dissolved oxygen data from the 1920s, 1960s and 1990s (Worthington, 1930; Hecky et al., 1994). The deep-water anoxia first observed in 1960-1961 (Talling, 1966), probably represented the earliest stage of eutrophication-induced deepwater oxygen loss in Lake Victoria (Figure 1a). Currently hypoxia has spread to shallow areas of the lake (Figure 1b). Studies have found $3 \mathrm{mgl}^{-1}$ to be the critical DO concentration below which most fish in Lake Victoria will not survive (Kaufman, 1992, Wanink et al., 2001).

Calamari et al., (1995) noted that phosphorus was the limiting factor for primary production in Lake Victoria. Discharge of phosphorus into the lake is possibly the main factor leading to eutrophication, with its concentration having increased by a factor of 2 to 3 (Mugidde et al., 2005). Phosphorous which disrupts normal biogeochemical cycles is mainly from human activities like; deforestation, agricultural activities and municipal wastes. High nutrient concentration support elevated primary production and algal biomass has risen by up to a factor of 8 (Mugidde et al., 2005; Lung'ayia et al., 2000). As more organic matter is produced more oxygen is needed to remineralize the organics, primarily through the microbial loop. The lake ecosystem becomes overloaded and DO declines leading to hypoxia and anoxic conditions. Earlier on, the balance of lake productivity and its water quality was maintained by its faunal composition (Goldschmidt et al., 1993). However, anthropogenic activities and introduction of exotic species changed this balance. The lake could no longer maintain its integrity; it changed from a mesotrophic system in the 1920s, dominated by diatoms, to a eutrophic system dominated by blue-green algae (Hecky et al., 1994; Lung'ayia et al., 2000). 
a)

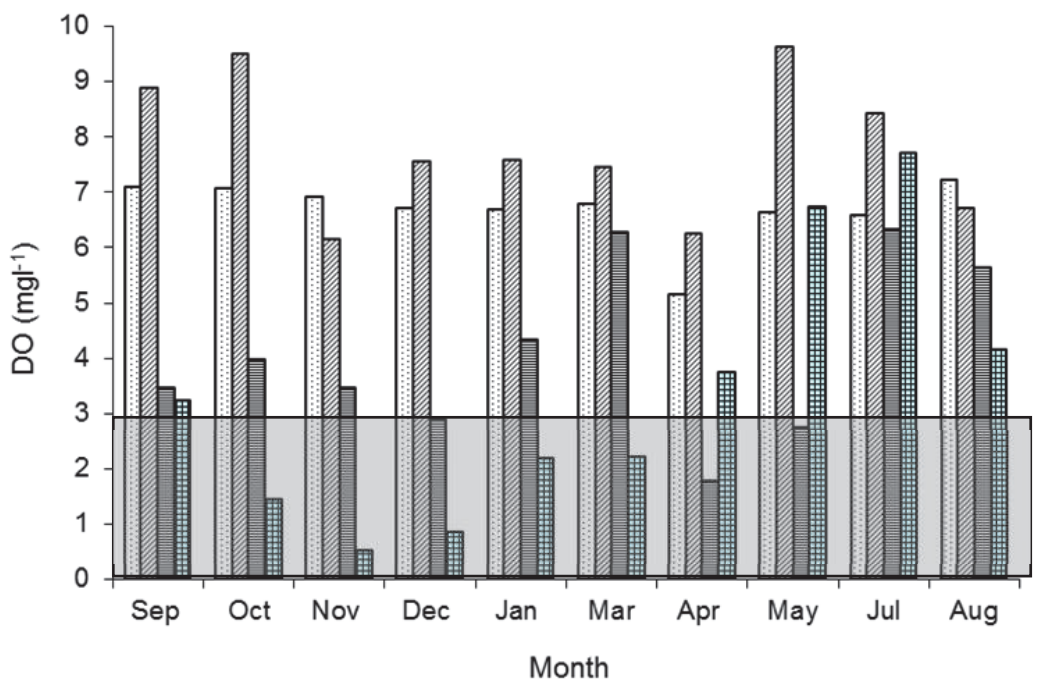

b)

DO $\left(\mathrm{mgl}^{-1}\right)$

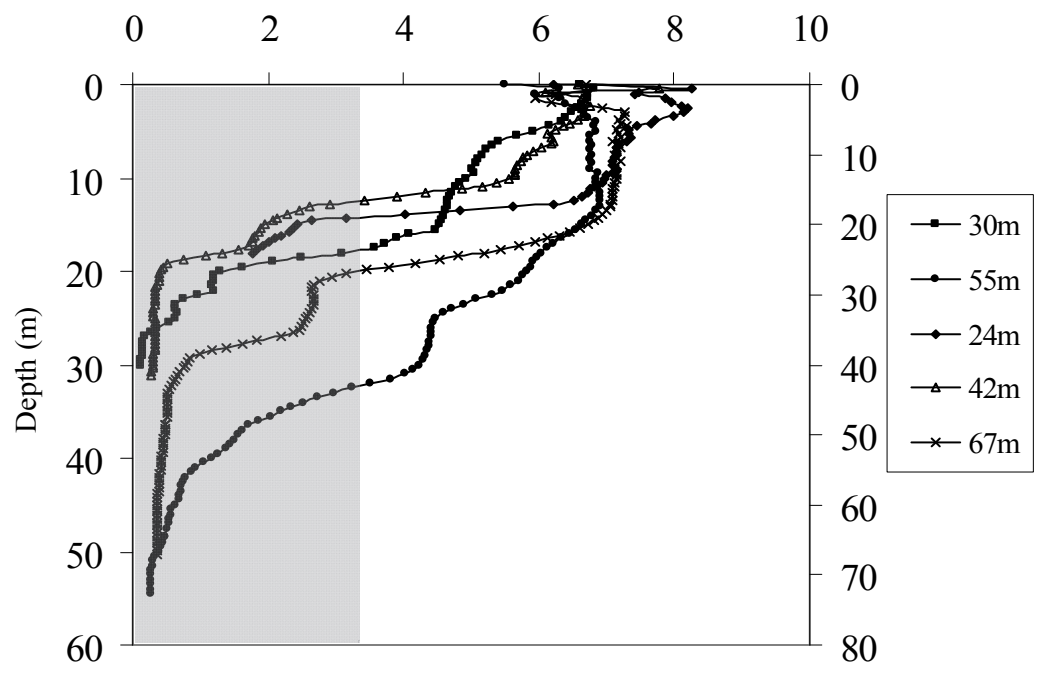

Fig. 1. Oxygen conditions in Lake Victoria, a) monthly oxygen levels with depth during 1960-61 (Talling, 1966) and 1990-1991 (Hecky et al., 1994), b) Oxygen profiles in February 2002 during stratification. The vertical grey bar represent oxygen concentration $\left(<3 \mathrm{mgl}^{-1}\right)$ considered critical for fish in the lake. Data Source, Kenya Marine and Fisheries Research Institute (KMFRI). 


\section{Stratification and hypoxia}

Depending on temperature and salinity, water contains 20-40 times less oxygen by volume and diffuses about ten thousand times more slowly through water than air (Graham, 1990). The relative low solubility and diffusion of oxygen in water combined with density stratification and decomposition lead to the development of hypoxia. Due to low solubility, small changes in amount of DO in water such as from microbial and macrofaunal respiration leads to large differences in oxygen saturation in water. For example, $9.1 \mathrm{mg} \mathrm{O}_{2} \mathrm{l}^{-}$ ${ }^{1}$ will dissolve in a liter of freshwater at $20{ }^{\circ} \mathrm{C}$; at this temperature a $1 \mathrm{mg} \mathrm{O}_{2} \mathrm{l}^{-1}$ drop in oxygen is equivalent to an $11 \%$ decline in oxygen saturation (Graham, 1990). Stratification of the water column isolates the bottom water from exchange with oxygen-rich surface water and the atmosphere, while decomposition of organic matter in the isolated bottom water consumes dissolved oxygen. For lakes, factors affecting vertical water mixing such as wind and temperature can lower DO in bottom waters to anoxic levels.

In Lake Victoria, thermal stratification, leading to hypoxia, was observed in the late 1920s (Worthington, 1930). Hypoxia conditions were restricted to the deeper waters $(>60 \mathrm{~m})$ and for shorter periods during the rainy season (Talling, 1966). Lake Victoria has three phases of thermal stratification; moderate stratification occurs between September and December, stable stratification in January to March/April, deep strong mixing in June to July (Talling, 1966; Mugidde et al., 2005). Global climatic change has affected this stratification, with the lake now warmer and thermal stratification more stable than in 1960s (Hecky et al., 1994). The overall minimum water temperature during the mixing period in June to July is $0.5^{\circ} \mathrm{C}$ warmer than in the 1960s (Hecky et al., 1994). Increase in deep-water temperatures, increases thermal stratification stability (Hecky et al., 1994). Thermal stability makes the lake less able to mix effectively and promotes low oxygen conditions in deep waters during stratification period between September and April (Tables 1, 2; Mugidde et al., 2005).

\begin{tabular}{|c|c|c|c|c|c|}
\hline \multirow{2}{*}{ Month } & \multicolumn{2}{|c|}{ Temperature $\left({ }^{\circ} \mathrm{C}\right)$} & \multicolumn{2}{|c|}{ Dissolved oxygen $\left(\mathrm{mgl}^{-1}\right)$} & \multirow{2}{*}{$\begin{array}{c}\text { Mixing depth } \\
(\mathrm{m})\end{array}$} \\
\hline & surface & bottom & surface & bottom & \\
\hline January & 27.4 & 26.4 & 8.3 & 2.1 & 12.0 \\
\hline March & 28.1 & 26.9 & 9.7 & 4.4 & 8.0 \\
\hline July & 25.3 & 24.3 & 10.6 & 6.2 & 20.0 \\
\hline August & 25.9 & 25.3 & 6.6 & 0.04 & 10.0 \\
\hline October & 25.6 & 25.4 & 5.8 & 1.3 & 6.0 \\
\hline November & 27.7 & 25.8 & 9.8 & 0.5 & 6.0 \\
\hline December & 26.8 & 23.9 & 7.0 & 0.6 & 8.0 \\
\hline
\end{tabular}

Table 1. Temperature and dissolved oxygen from an inshore shallow station (Napoleon Gulf, Uganda) in Lake Victoria. Boldface represents bottom DO levels during stratification period. Source: Mugidde et al. (2005).

Elevated water temperature accelerates algal productivity, chemical reactions and microbial processes such as denitrification-nitrification affecting nitrogen cycling and availability, resulting in a build up of regenerated nutrients in bottom waters. Resulting low oxygen conditions allow return of phosphorus from bottom to surface, but not nitrogen (Hecky et al., 1994, Mugidde et al., 2005). Continuous $\mathrm{N}$ loss due to denitrification during persistent stratification leads to high $\mathrm{N}$ demand and favours growth of blue-greens including $\mathrm{N}$-fixers 


\begin{tabular}{llllcc}
\hline Month & \multicolumn{2}{c}{ Temperature $\left({ }^{\circ} \mathrm{C}\right)$} & \multicolumn{2}{c}{ Dissolved oxygen $\left(\mathrm{mgl}^{-1}\right)$} & $\begin{array}{c}\text { Mixing depth } \\
\text { surface }\end{array}$ \\
& surface & bottom & & \\
& & & & & \\
\hline March & 26.7 & 24.4 & 8.2 & $\mathbf{0 . 4}$ & 25.0 \\
May & 26.6 & 25.7 & 7.7 & 5.6 & 40.0 \\
July & 25.4 & 25.1 & 6.1 & 6.0 & 65.0 \\
September & 26.6 & 24.4 & 9.0 & 4.7 & 40.0 \\
November & 27.7 & 25.8 & 11.0 & $\mathbf{2 . 2}$ & 30.0 \\
December & 25.2 & 24.7 & 7.4 & $\mathbf{2 . 4}$ & 30.0 \\
\hline
\end{tabular}

Table 2. Temperature and dissolved oxygen from offshore deep station $(70 \mathrm{~m})$ in Lake Victoria. Boldface represents bottom DO levels $\left(<5 \mathrm{mgl}^{-1}\right)$ during stratification periods. Source, Mugidde et al. (2005).

as light in the euphotic zone is adequate during this time of the year. Recent studies have showed that the lake is continuously hypoxic below $50 \mathrm{~m}$ depth especially during stratified period, while areas between 25 and $50 \mathrm{~m}$ are more subject to frequent severe hypoxia (Figure 1b, Table 1). Even in the littoral waters, low values have been measured near the bottom (Wanink et al., 2001). For example, during a 2-year-long monthly sampling programme at an $8 \mathrm{~m}$ deep station, a pronounced hypoxia at the bottom (DO of 2-3 $\mathrm{mgl}^{-1}$ ) was regularly recorded in Mwanza Gulf of Lake Victoria (Akiyama et al., 1977).

\section{Introduced species and hypoxia}

Prior to the current ecological changes, intense fishing and introduction of exotic species, Lake Victoria ecosystem was able to counteract hitherto perturbations (Ogutu-Ohwayo, 1990). Phytoplanktivores and detritivorous haplochromines cichlids constituted the highest number of species and biomass in the lake up to late 1980s (Figure 2a). Haplochromines were able to crop and digest algae maintaining a healthy lake ecosystem (Goldschmidt et al., 1993). Predation by Nile perch and intensive fishing led to dramatic decline of haplochromine stocks. By late 1980s, haplochromines could no longer be caught in trawls at 8-50 m depth where formerly they were numerous (Witte et al., 1992a, 1992b). Over 90\% of sublittoral and deep-water haplochromine stocks declined between 1968 (Kudhogania \& Cordone, 1974), and 1986 (Witte et al., 1992b). Nile perch is believed to have contributed to a bottom-up and a top-down increase in hypoxia in the lake. Nile perch, an apex piscivore, is largely responsible for the near decimation of the detritivorous and phytoplanktivorous haplochromine cichlids (Ogutu-Ohwayo, 1990, 1994). Studies have shown that during its boom between late 1960s and early 1980s, the perch fed mainly on haplochromines (Figure 3a). Between late 1980s and early 1990s, haplochromines were rare in the diet of Nile perch, whereas invertebrates (primarily Caradina nilotica), $R$. argentea, and juvenile Nile perch were more frequent (Figure 3b; Mkumbo \& Ligtvoet, 1992). This dietary shift coincided with the dramatic decline of haplochromines (Figure 2a). Between 1997 and 2010 haplochromines became again more prominent in Nile perch diet (Figure 3c-f). The shift in diet corresponded with resurgence of haplochromines in the lake. Loss of phytoplanktivorous and detritivorous haplochromines, accelerated algal production, increased eutrophication led to increased deep water hypoxia (Goldschmidt et al., 1993). Witte et al., (1992a) argued that the impact of the Nile perch on the haplochromine cichlids was much greater than that of fishing. For example, haplochromines declined dramatically in large areas with low fishing pressure such as the Emin Pasha Gulf. 
a) $\quad-\cdot-$ Haplochromines
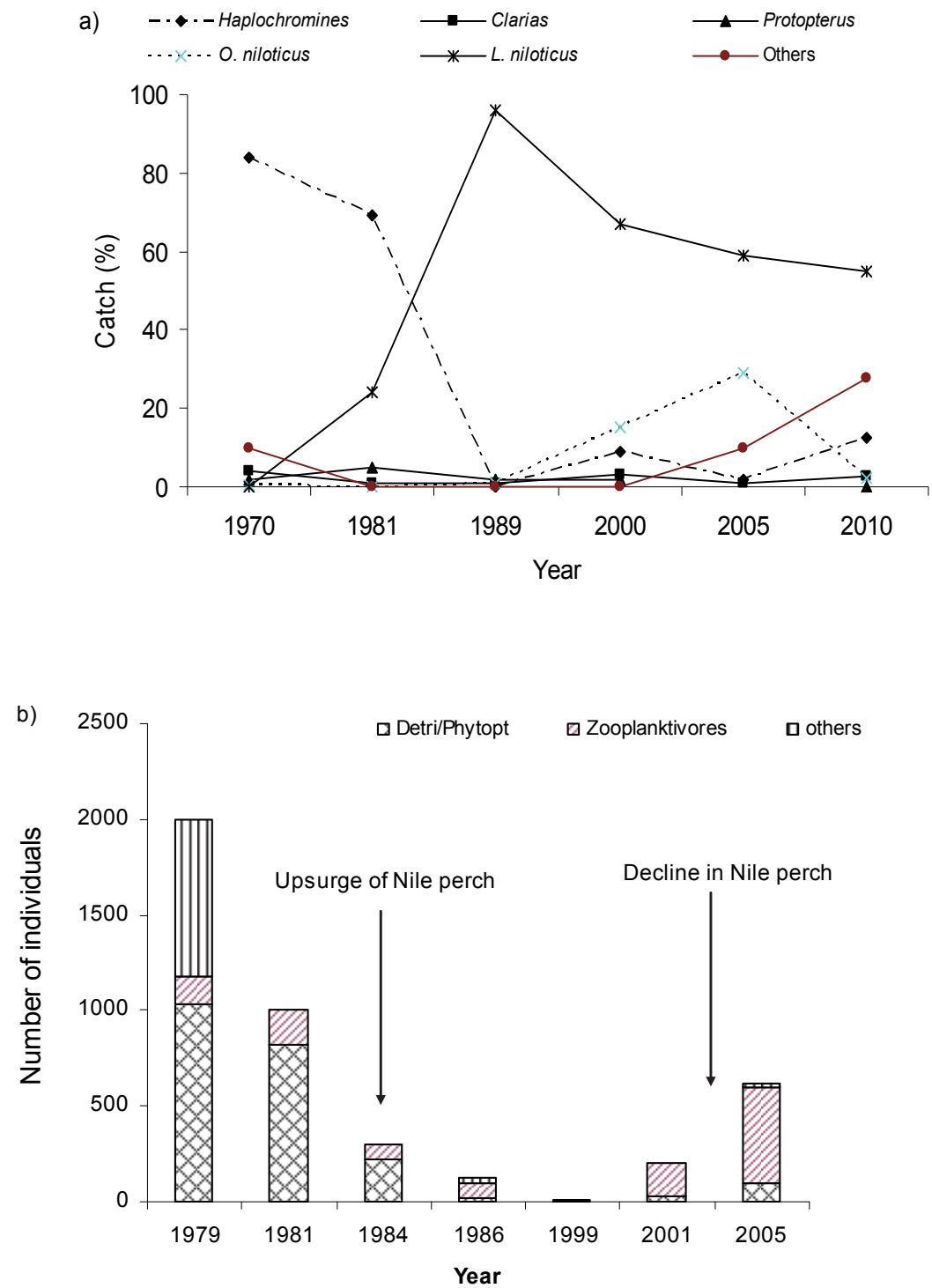

Fig. 2. Trends in haplochromine catches in Lake Victoria, a) bottom trawl catches in Nyanza Gulf, Kenya. Others = Synodontis spp, Brycinus spp. Bagrus docmak. Source: 1970- 2004. Njiru et al., (2005), 2010, KMFRI, b) trophic groups in Mwanza Gulf, Detri/Phytopt = detritivores/ phytoplanktivores, others = remaing trophic groupings (e.g., piscivores, insectivores, molluscivores). Source: Witte et al. (2007).

Unlike the small haplochromines, the relatively fat large Nile perch could not be dried in the sun (Riedmiller, 1994). Big fish was chopped into pieces and deep fried in their own fat 
while the smaller Nile perch were mainly smoked (Ligtvoet et al., 1995). For instance, at Wichlum Beach (Kenya), the number of smoking kilns increased between 1984 and 1991 from about 10 to over 50 (Riedmiller, 1994). For frying and smoking purpose, firewood used enhanced the deforestation along the lake's shore, exposing land to increased erosion and increased nutrients inputs into the lake. High nutrient levels led to high rates of photosynthesis and phytoplankton blooms created nearly continuous super-saturation in surface waters (Hecky et al., 1994). Subsequently, microbial breakdown led to reduction in DO in the bottom waters creating anoxic areas.

The exotic Nile tilapia is associated with negative effects on native tilapias $(O$. variabilis, $O$. esculentus) which included hybridization, overcrowding, competition for food, and possibly introduction of parasites and diseases (Trewavas, 1983; Ogutu-Ohwayo, 1990). The Nile tilapia, which is more fecund, grows faster, feeds on a variety of food items, and generally is a better competitor for resources displaced the native tilapias (Trewavas, 1983; Njiru et al., 2004).

Ecological changes in the lake, including oxygen availability, were further affected by invasion of water hyacinth, Eichhornia crassipes a native to South America in 1989 (Twongo et al., 1995). The weed invasion had significant socioeconomic and environmental impacts and affected water quality (Twongo et al., 1995; Njiru et al., 2002). Shading of the water by the hyacinth curtailed photosynthesis, while microbial breakdown of decaying plant material used the available oxygen. The waters below water hyacinth recorded DO as low as $0.1 \mathrm{mgl}^{-1}$ making it inhabitable to most fish (Njiru et al., 2002). Additionally, the weed affected distribution of fish by blocking migratory routes of those escaping low DO and predation (Balirwa et al., 2003). However, studies by Njiru et al., (2002) found the hyacinth to have led to recovery of the native species which where more hypoxia tolerant such as catfishes, lungfish and tilapia (Figure 4).

\section{Fish kills}

Dissolved oxygen is one of the main factors influencing the distribution of fish in lakes (Kramer,1987; Wanink et al., 2001). In warm waters, fish generally die when exposed to DO concentrations lower than $1.5 \mathrm{mgl}^{-1}$ (Miranda et al., 2000). At this concentration, the partial pressure of DO, approximately $\pm 35 \mathrm{~mm} \mathrm{Hg}$, is only marginally grater than venous $\mathrm{O}_{2}$ pressure of fish, $30 \mathrm{~mm} \mathrm{Hg}$ (Perry \& McDonald, 1993). Fish kills is more likely from aperiodic hypoxia, with complete avoidance of persistent hypoxia (Diaz \& Breitburg, 2009). Episodes of hypoxia may lead to changes in community composition, a decline in faunal diversity and decrease in fisheries production. In Lake Victoria, thermal stratification which enhances chemical reactions favouring the accumulation of toxic organic compounds and anoxic conditions has led to fish kills. Ochumba (1990) reported massive kills of Nile perch and O. niloticus in Nyanza Gulf of Lake Victoria which he attributed to low $\mathrm{pH}$ and low dissolved oxygen level, combined with physical clogging of the gills by suspended detritus and algae. The adverse conditions were as a result of massive algal blooms and their subsequent microbial breakdown in the lake. More than $80 \%$ of the dead Nile perch were adult fish (> $60 \mathrm{~cm}$ TL). The disproportionate number of large fish that died might have been related to a smaller gill surface area, relative to their biomass, compared to smaller fish. Moreover, smaller fish might be better at utilizing DO at the water's surface. Similarly, Fish 


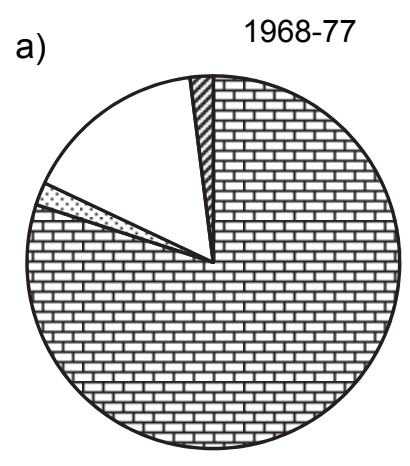

b) 1988
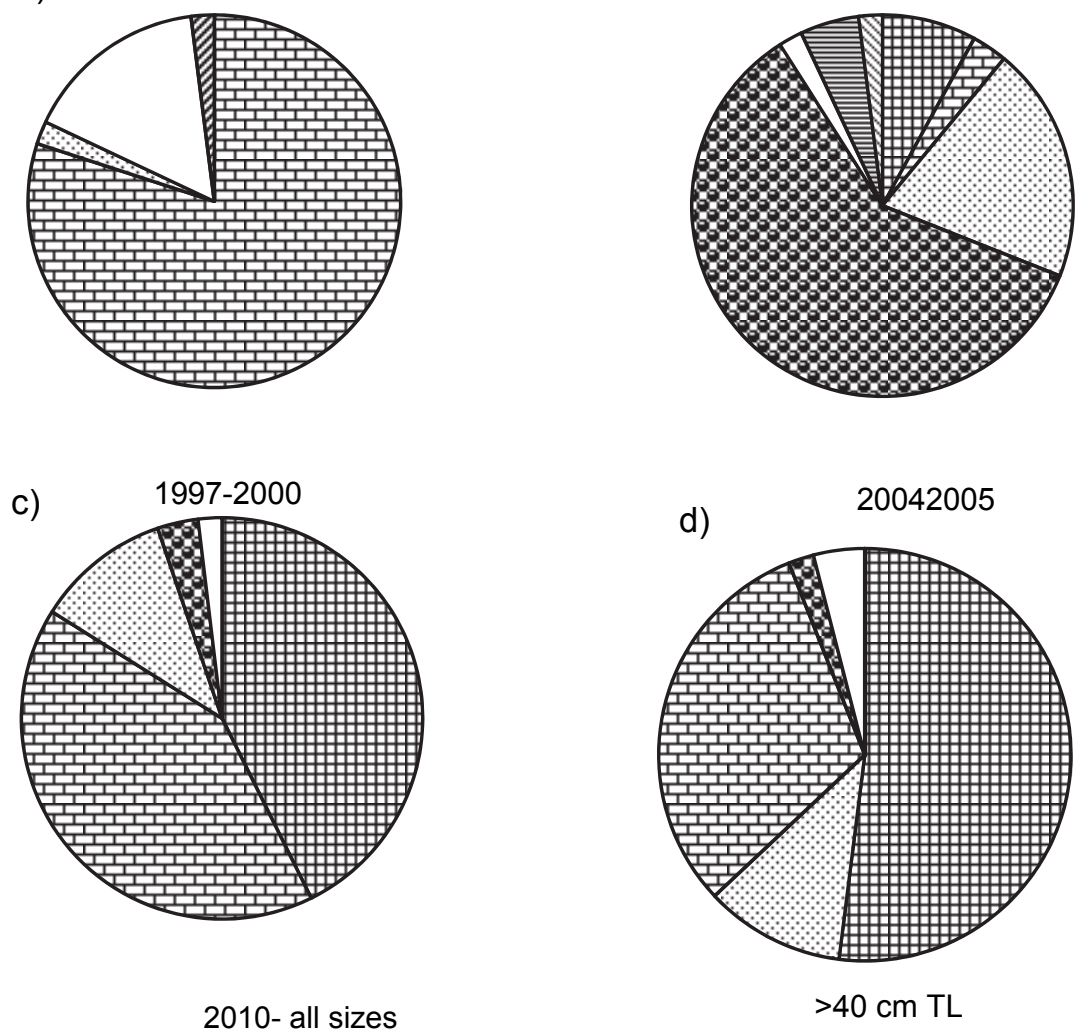

e)
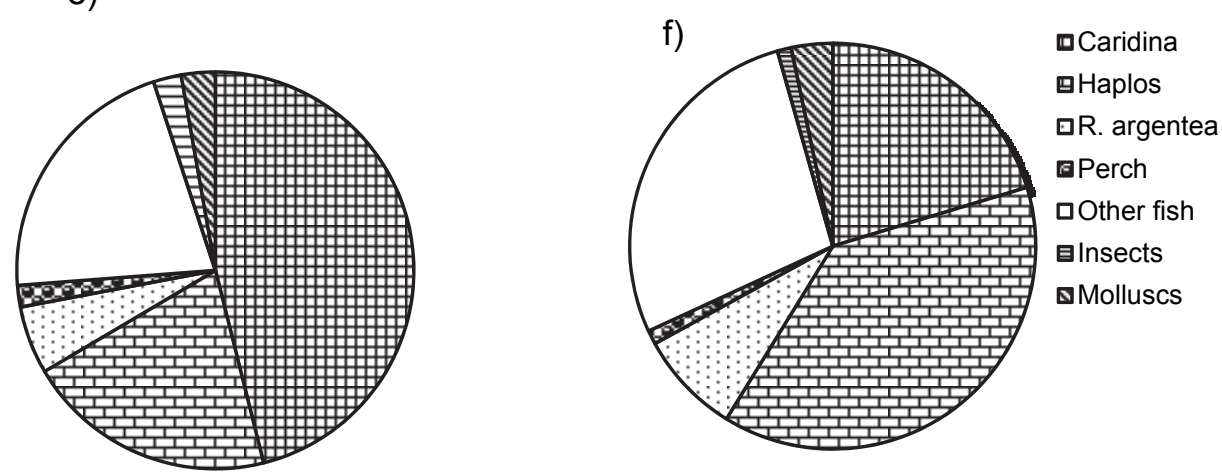

Fig. 3. Diet of L. niloticus in Lake Victoria; a) 1968-1977, (b) 1988, c) 1998-2000, d) 2004-2005, e) \& f) 2010. Haplos = Haplochromines, Others = include Synodontis, Clarias, Tilapias. 19682005 data adapted from Njiru et al., (2005), 2010 data from KMFRI. 


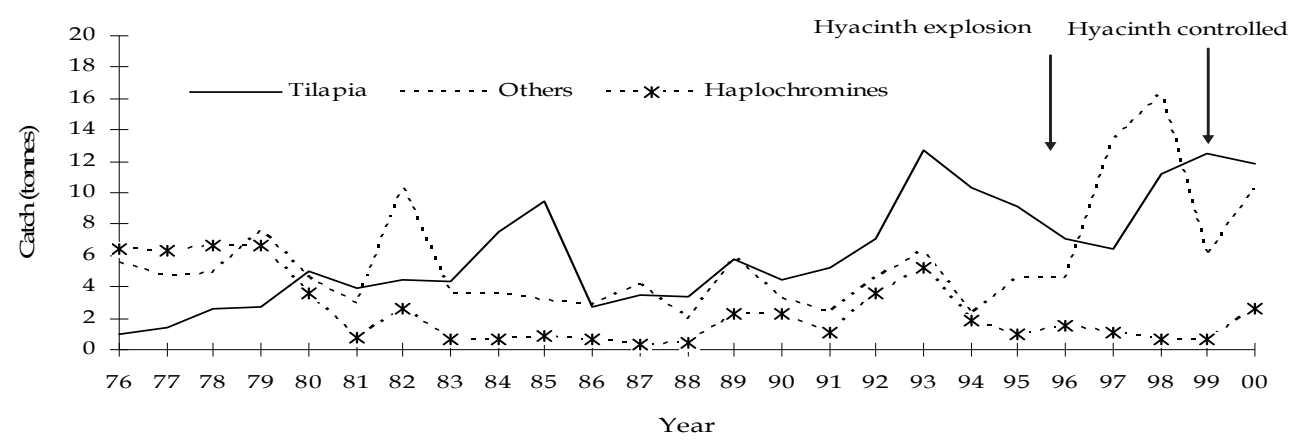

Fig. 4. Annual catches of haplochromines, tilapines and other species (mainly Clarias Protopterus, Synodontis) in Lake Victoria, Kenya. Source: Njiru et al., (2005).

(1956) recorded fish kills in Lake Albert which he attributed to sudden decrease in dissolved oxygen and increased carbon dioxide. Of the dead fish, 70\% were adult Nile perch. He suggested that the larger fish were more dependent on optimum aeration conditions than smaller fish. Lower numbers of dead Nile tilapias were in the records probably due to its higher tolerance to low DO and habitat restriction in relatively shallow waters.

Further, Kaufman and Ochumba (1993) using a remote operated vehicle in Lake Victoria found large numbers of dead or dying $R$. argentea below the oxycline. The authors suggested that rapid shifts in the oxycline may have caused the mass mortality. In contrast to Nile perch, $R$. argentea may sink to the bottom after dying from a sudden deoxygenation of the habitat, leaving no evidence of a kill at the surface. Wanink et al., (2001) reported massive kills of fish (mainly Nile perch) in Mwanza Gulf following severe storm, a drop in the depth of the oxycline and a subsequent sudden upwelling of hypoxic water. The stomachs of most floating Nile perch were extruded probably caused by expansion of the swim bladder, which suggested that the fish had risen quickly to the surface, driven there by upwelling hypoxic water. Other causes of fish death in Lake Victoria such as Aluminium and unionized ammonium toxicity are discounted due to their low concentrations and the slightly acidic condition (Hecky et al., 1994; Wanink et al., 2001). The absence of dead lungfish, $P$. aethiopicus and C. gariepinus further supports the evidence that the fish were killed by hypoxia. Lungfish can breathe atmospheric air while C. gariepinus has an accessory organ that enables it to extract oxygen from the air in waters with low concentration.

\section{Oxycline as refugia}

Prey species of Nile perch may find refugia in hypoxic habitats, since this predator is thought to be extremely sensitive to low oxygen levels (Kaufman, 1992). Support for this 'hypoxic predation refugium' hypothesis came from exploratory dives by a remote operated vehicle, which filmed dagaa shoaling near the oxycline (Kaufman \& Ochumba, 1993). Nile perch was in waters with a higher DO, but made short foraging grips into the hypoxic layer. According to Hecky et al., (1994) the hypoxic deep-water area may have originally functioned as a refugium for the haplochromines that had lower critical DO levels than Nile perch. The increasing deoxygenation $\left(<1 \mathrm{mgl}^{-1}\right)$ of the deep water might have forced the demersal populations to the shallower waters, where they were exposed to Nile perch 
predation. Chapman et al., (1995) further, suggested that some species that were thought to have disappeared could have sought refuge in low oxygen areas or near the oxycline in deeper waters that were not adequately sampled.

However, the ability of Nile perch to dive below the oxycline limited the use of these habitats as a refugium. Wanink et al., (2001) showed presence of Nile perch at concentrations of oxygen of less than $3 \mathrm{mg} \mathrm{O}_{2} \mathrm{l}^{-1}$ to be common (Figure 5). Wanink et al., (2001) refutes the fact that $R$. argentea benefited from low oxygen refugia. The authors found no difference in the levels at which dissolved oxygen starts to limit the distributions of $R$. argentea and Nile perch. Nile perch may even cope better with extreme hypoxia than $R$. argentea, since at levels below 1-2 mg O $\mathrm{I}^{-1}$ the cumulative catch of Nile perch was higher than that of dagaa. In addition, it is likely that the critical oxygen level that limits Nile perch distribution in the field is lower than $5 \mathrm{mg} \mathrm{O}_{2} \mathrm{l}^{-1}$, the level used in the hypoxic predation refugium hypothesis. This level is based on experiments by Fish (1956), who found that, in the absence of carbon dioxide, the Haemoglobin of Nile perch cannot be fully saturated unless the water in contact with the gills contains at least $5 \mathrm{mg} \mathrm{O}_{2} \mathrm{l}^{-1}$. Up to now no studies have shown that Nile perch are limited to water in which their haemoglobin is fully saturated. Equally, bottom trawling in Mwanza Gulf of Lake Victoria yielded high Nile perch catches throughout the period 1986- 87 (Ligtvoet \& Mkumbo, 1990), whereas a previous limnological study in that area had shown that the level of dissolved oxygen near the bottom was below the level of $5 \mathrm{mg} \mathrm{O}_{2} \mathrm{l}^{-1}$ for several months per year (Akiyama, et al., 1977).

Besides, haplochromine cichlids which fed on the bottom also declined dramatically in catches (Witte et al., 1992a, 1992b; Goldschmidt et al., 1993). The disappearance was attributed to hypoxia and predation by Nile perch. Verschuren et al., (2002) suggested that deoxygenation of deep water have eliminated critical haplochromine refugia, exacerbating the vulnerability of haplochromine cichlids to Nile perch predation. Haplochromine cichlids may have faced the choice of death by asphyxia in the deep anoxic water or predation by the Nile perch in the oxygen-rich shallow waters. Nonetheless, Wanink et al., (2001) noted that an increasing thickness of the hypoxic layer with distance from shore could limit movement of Nile perch. This scenario would allow hypoxia tolerant species to seek refugia and feeding grounds in the deeper waters below the oxycline. For example, invertebrate species capable of tolerating low DO may use hypoxic benthic areas in stratified lakes as refugia to avoid fish predation (Kaufman, 1992). Increasing hypolimnetic anoxia in Lake Victoria coincided with changes in the macroinvertebrate community. There has been a notable increase of the detritivorous shrimp Caridina nilotica, chironomids and mayflies, Povilla adusta (Witte et al., 1992a, 1992b; Goldschmidt et al., 1993). These invertebrates probably use low-oxygen water as refugia from Nile perch predation. They may also be exploiting increased availability of algal and detrital foods, caused by the disappearance of the haplochromines (Kaufman, 1992; Goldschmidt et al., 1993).

\section{Wetlands and rocky habitats}

Studies in Lake Victoria and its satellite lakes suggest that wetlands and rocky habitats play a crucial role in predator-prey interactions (Chapman et al., 1996). Prey tolerant to high hypoxia may seek refugia in wetlands which are less accessible to less tolerant predators. The well-oxygenated rocky shores and offshore rocky islands may also serve as important 

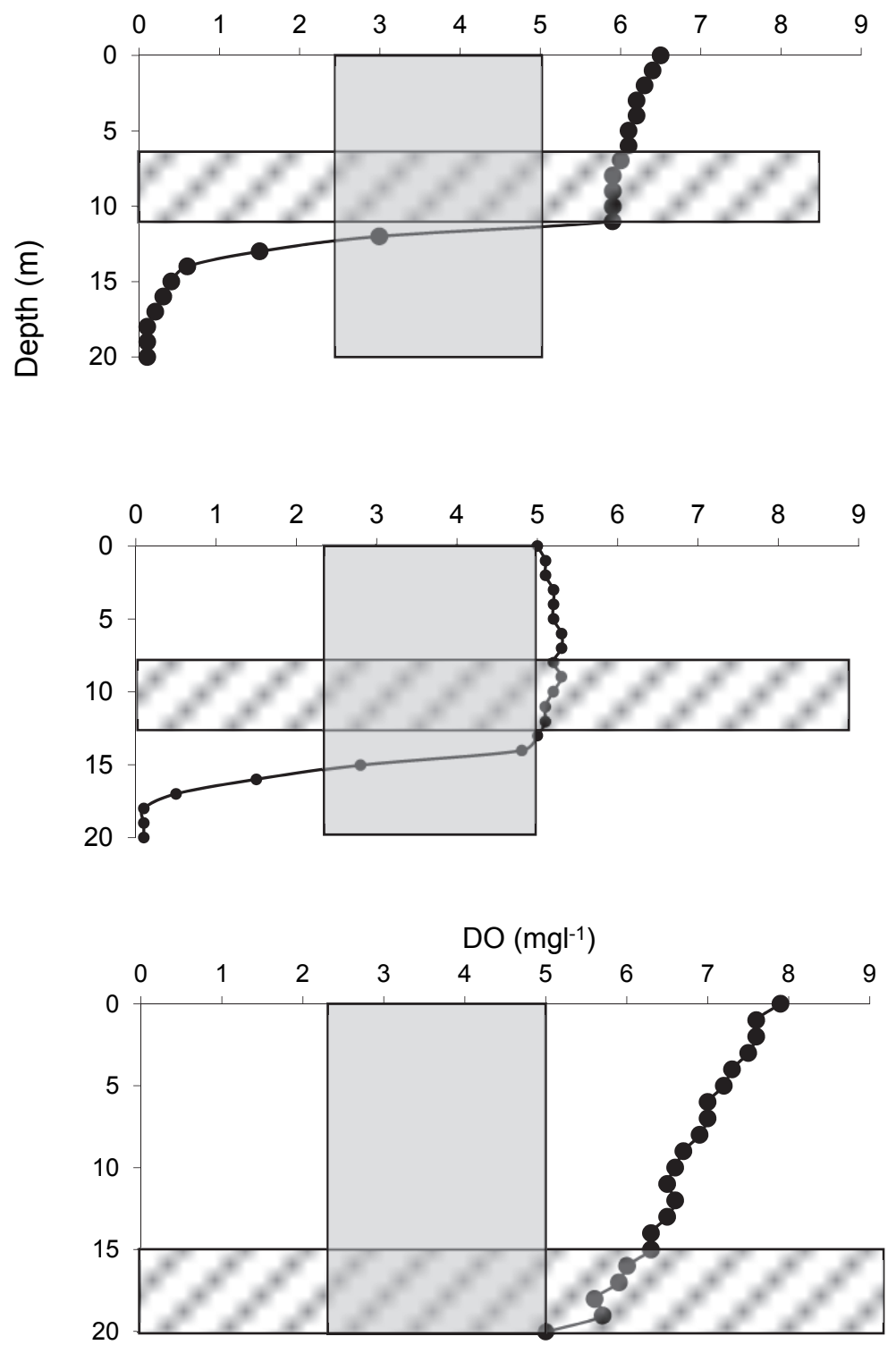

Fig. 5. Day-time depth distribution of adult $R$. argentea in relation to the depth of the oxycline in Mwanza Gulf, Lake Victoria on three different days in 1988 (from top to bottom: April 28, February 25 and October 14). Hatched bars represent levels at which $R$. argentea was caught. The vertical grey bars represent the oxygen concentration below the level needed by Nile perch to fully saturate their Haemoglobin (Fish, 1956), at which their abundance did not seem limited. Source: Wanink et al. (2001). 
refugia because of their high structural complexity (Seehausen et al., 1997). Wetlands and rocky crevices are believed to have mitigated the impacts of predaceous Nile perch allowing survival of some native fish species (Witte et al., 1992a; Seehausen et al., 1997; Chapman et al., 1996). Wetlands around Lake Victoria and its satellite lakes are typically dominated by stands of Miscanthidium violaceum or Cyperus papyrus which form dense canopies. Light and wind hardly infiltrate the swamp canopy and both plant growth and decomposition proceed at high rates (Chapman et al., 1996). Gradients of very low levels of oxygen are created from the interior of the swamp to the open waters (Schofield \& Chapman, 2000). Environmental conditions in wetlands are variable with DO oscillating from $0.1 \mathrm{mgl}^{-1}$ to 7.0 $\mathrm{mgl}^{-1}$ in less than 12 hours (Chapman et al., 1998). The hypoxic conditions in wetlands function as barriers to dispersal of Nile perch (Chapman et al., 1996; 2002; Schofield \& Chapman, 2000), and act refugia for more hypoxia tolerant fish species. Unlike the oxycline, where Nile perch can dive to get prey, the large areas of wetlands make it difficult for the perch to penetrate (Chapman et al., 1995; 1996; 2002; 2003; Rosenberger \& Chapman, 1999).

Experimental work on Lake Victoria cichlids, initially the principal prey of the introduced Nile perch, showed generally high levels of hypoxia tolerance (Chapman et al., 1995). The authors suggested that some cichlids may have used the structural complexity of the rocky, littoral waters and fringing swamps as a defense against Nile perch. This suggestion is supported by relatively high haplochromine survival in rocky shore habitats and wetlands of Lake Victoria (Witte et al., 1992a,1992b; Seehausen et al., 1997). In Lake Nabugabo, haplochromine cichlids are more confined to inshore areas, particularly the wetland ecotones (Chapman et al., 1996; Schofield \& Chapman, 2000). The overlap between Nile perch and indigenous species was greatly reduced in the ecotone areas. Juvenile Nile perch (8.6-42.2 cm, TL) were 3.7 times more abundant in offshore exposed areas than in inshore areas near wetland ecotones. Stomach analysis of Nile perch found fewer haplochromines and indigenous species in fish caught in ecotonal zones compared to exposed habitats. This suggested that the ecotone of the wetland/open water acted as a refugium probably due to higher DO and structural complexity.

However, recent studies have found a larger proportion of Nile perch near wetland ecotones with DO as low as $0.96 \mathrm{mgl}^{-1}$ than in the mid 1990s (Paterson \& Chapman, 2010). These juveniles penetrating the hypoxia zones had bigger gill sizes than their counterparts in the open waters. The advantage of Nile perch occupying wetland ectones was probably to maximize prey capture, and seek refuge from cannibalism and intense fishing. Although intense fishing pressure on Nile perch coincided with faunal resurgence in Lake Victoria, it is possible that other environmental changes have contributed to the observed patterns (Njiru et al., 2002). The resurgence in native species in the early 2000s coincided with the lake invasion by water hyacinth. The hypoxic water beneath the mats may have acted as a refuge for native species such as haplochromines, catfishes and lungfish that are less sensitive to low oxygen levels than Nile perch (Njiru et al., 2002). The hyacinth mats reduced fishing pressure allowing a recovery of these species. Similar observations were recorded in Lake Kyoga, a satellite of Lake Victoria following spread of water hyacinth (Ogutu-Ohwayo, 1994). Several other satellite lakes that have not experienced introduction of Nile perch still retain the original fish fauna similar to that of Lake Victoria in the 1950s (Maithya, 1998). For example, the extirpated species of $O$. variabilis and O. esculentus in Lake Victoria are abundant in Lake Kanyaboli in Kenya. It is argued that the wetlands, satellite 
lakes and rocky refugia may modulate extinction in the Lake Victoria by acting as source of resurging species (Kaufman et al., 1997; Chapman et al., 2003)

\section{Behaviour adaptation to hypoxia}

Fishes have evolved a variety of solutions to hypoxic stress which vary among species, life stages, and habitats (Kramer, 1987; Chapman \& McKenzie, 2009). Well-documented responses to short-term hypoxia include behavioral and physiological mechanisms as avoidance, increased aquatic surface respiration, increased gill ventilation activity, reduced motor activity, and reduced metabolic scope, increased hemoglobin/hematocrit concentrations, and anaerobic metabolism (Rutjes, 2006; Pollock et al., 2007; Chapman \& McKenzie, 2009).

\subsection{Distribution}

For fishes, the level of dissolved oxygen is one abiotic factor that can limit habitat utilization (Kramer, 1983, 1987; Chapman \& Liem, 1995). Low-oxygen conditions may render the habitat inhabitable, change food availability, and act as barriers or biological filters to fish dispersal (Chapman et al., 1999). Habitat compression or habitat "squeeze" can occur where hypoxia overlaps with nursery habitats or makes deeper, cooler water unavailable (Domenici et al., 2007). Fish will be forced to seek alternative habitats or perish. Hypoxic conditions also shift the balance of the interaction to favour predator or prey depending on their relative tolerance of each (Domenici et al., 2007).

In Lake Victoria, severe hypoxic conditions $\left(<1.0 \mathrm{mg}^{-1}\right)$ now persists at depths below $40-50 \mathrm{~m}$ which cover about 35\% of the lake's total bottom area (Wanink et al., 2001). Even in shallow areas $(<20 \mathrm{~m})$ more hypoxic habitats are now frequently detected (Figure $1 \mathrm{~b})$. The shallow areas of the lake are the fish breeding and nursery grounds. Limnological studies indicated that between $40-50 \%$ of the fish habitat areas in the lake have been lost because of deoxygenation of its waters (Mugidde et al., 2005).

Studies show a relationship between catches and utilization of habitats in Lake Victoria. Recent acoustic studies showed that Nile perch catches increased with increase in oxygen concentrations (Figure 6). No fish were caught when DO was below $2.5 \mathrm{mgl}^{-1}$. These results concur with those of Wanink et al., (2001) on the same species. The authors caught no fish when DO was less than $0.2 \mathrm{mgl}^{-1}$, and catch rate increased rapidly with increased DO concentration. Bottom-trawl and gill-net surveys by Goudswaard et al., (2004), showed that zooplanktivorous haplochromines, $R$. argentea and piscivorous $S$. intermedius, dwelt near the bottom by day and migrated towards the surface at night. The trend seemed to be governed by prey availability. After the Nile perch boom, and following the decline of the haplochromines, $R$. argentea would invade the lower part of the water column by day (Wanink et al., 2001). Movement to the bottom was to exploit the increased stocks of benthic invertebrates, such as the shrimp C. nilotica and chironomid larvae. However, this changed following decreased levels of DO in the lake (Figure 5). When the lake is stratified, $R$. argentea spends the day just above the oxycline instead of near the bottom.

Before spread of hypoxia in the lake, the Nile tilapia stayed near the bottom during day and night (Goudswaard et al., 2004). This successful establishment of Nile tilapia in the lake was partly attributed to its ability to withstand a broad range of environmental variation (Njiru 


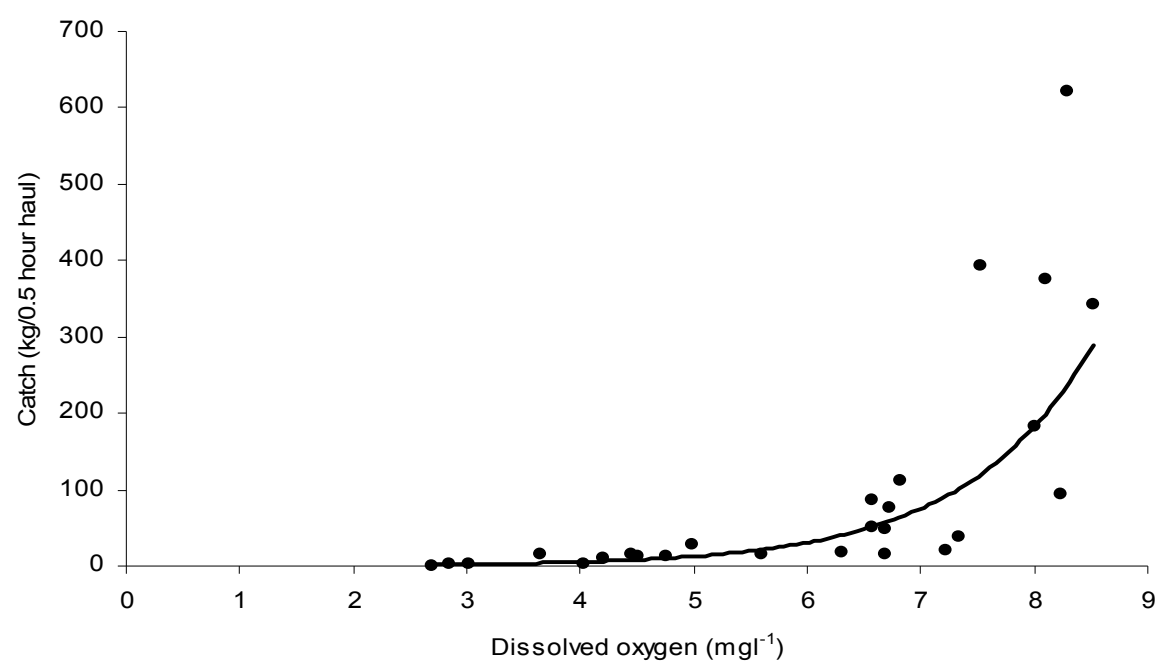

Fig. 6. Trends in Nile perch catches with oxygen in Lake Victoria, Kenya in 2010. Data from bottom trawl surveys, KMFRI 2010.

et al., 2004). Measurements of oxygen affinities in the lake for Nile tilapia $\left(\mathrm{P}_{50}=1 \mathrm{mmHg}\right)$ found the species to be hypoxic tolerant (Verheyen et al., 1986), enabling it to exploit the deeper waters and over mud bottoms. Nile tilapia juveniles are very tolerant of hypoxic stress and could even penetrate deep swamp refugia within the Lake Victoria basin (Chapman et al., 1996, 2002).

A study by Fish (1956) showed that mormyrid Mormyrus kannume Forsskål and the catfish B. docmak had $\mathrm{P}_{50}$ values ca. $1 \mathrm{~mm} \mathrm{Hg}$. Both species were caught up to depths of more than 60 $\mathrm{m}$ in the lake (Kudhongania \& Cordone 1974), which are normally hypoxic. Nile perch is a bottom dweller, but it may migrate into the water column when oxygen concentrations are insufficient near the bottom (Ligtvoet \& Mkumbo, 1990). The species has has been caught in Lake Victoria over a wide depth range of 1 to $60 \mathrm{~m}$ (Ligtvoet and Mkumbo, 1990). During its boom, the highest catch rates in the Lake Victoria were between the depths of 20 and $50 \mathrm{~m}$ deep (Ligtvoet and Mkumbo, 1990). A study by Fish (1956) revealed a $P_{50}$ value of $17 \mathrm{mmHg}$ for Nile perch (referred to as Lates albertianus), indicating that it is not hypoxia tolerant. Decreased oxygen levels in the lake have affected its distribution by confining it in areas with high DO. Recent studies revealed more hypoxia tolerant Nile perch (Paterson \& Chapman, 2010). In Lake Nabugabo, the perch with large sized gills which has better oxygen uptake, is penetrating the wetland which hitherto was out of bounds for the species.

Anoxia may have forced the demersal haplochromine populations (Witte et al., 1992a,1992b; Kudhongania \& Cordone, 1974) to shallower water where they are exposed to Nile perch predation. Nile perch require high concentrations of oxygen (Fish 1956), while some haplochromines can tolerate oxygen as low as 2-3 $\mathrm{mgl}^{-1}$ for extended periods (Van Oijen et al., 1981). The survival and eurytopic distribution of Pseudocrenilabrus multicolor victoriae Seegers in the lake basin is attributed to high flexibility tolerance to hypoxia (Chapman et 
al., 1996, 2002; Rosenberger \& Chapman, 2000). The species was able to exploit hypoxic refugia such as dense wetlands which gave it an advantage over other haplochromines during the Nile perch boom period. Complete mixing of the lake occurs around June to July resulting in almost uniform distribution of nutrients and dissolved oxygen (Hecky et al., 1994; Mugidde et al., 2005). More oxygenated water allows fish to occupy deeper zones of the lake. The lake tends to have low densities of fish during mixing as fish are more widely distributed throughout the lake. The more tolerant species such the catfishes (Clarias, Synodontis, Mormyridae) and air breathing P. aethiopicus are found in swamps and deep waters dominated by low DO (Chapman \& Liem, 1995; Chapman et al., 1996), where chronically low oxygen conditions may not limit their dispersal.

\subsection{Aquatic surface respiration}

Aquatic surface respiration (ASR) involves rising to the surface and ventilating the layer of water in contact with the atmosphere, which is richer in DO than the underlying bulk of water (Chapman \& McKenzie, 2009). ASR is a pronounced behavioral response by bony fishes to aquatic hypoxia. This behavioral responses to hypoxia can influence other critical components of fishes in their environment, including habitat use and selection, predatorprey interactions, competitive interactions, and patterns of aggregation. A major ecological benefit to the performance of ASR is that it allows fish to colonize hypoxic refugia that less tolerant predatory species cannot occupy successfully (Chapman et al., 1995, 2002; Rosenberger \& Chapman, 1999). For example, Chapman and Chapman (1998) reported remnant populations of a small mormyrid, Petrocephalus catostoma (Günther), in wetland lagoons surrounding Lake Nabugabo a satellite lake of Lake Victoria, after its population had disappeared from the main lake following the introduction of Nile perch. This tiny electric fish survives by virtue of a low metabolism, a low critical oxygen tension, large gill surface area, and inverted swimming during ASR to expose its subterminal mouth to the surface of the water.

Experiments on response to short-term low DO regime in cichlids from Lake Victoria (haplochromines, Nile tilapia and O. eculentus), revealed a well-developed ASR (Chapman et al., 1995). Astatoreochromis alluaudi Pellegrin which is widely spread in Lake Victoria basin showed a well-developed ASR and no loss of equilibrium during acute hypoxia (30 minutes at $<0.2 \mathrm{mg} \mathrm{l}^{-1} \mathrm{DO}$ ). In contrast, the rock-dwelling $\mathrm{H}$. (Neochromis) rufocaudalis (= N. nigricans in Chapman et al., 1995), which normally lives in shallow well-oxygenated water, lost equilibrium more quickly than other species. When there was no access to the surface only the native tilapiine O. esculentus and the introduced Nile tilapia did not lose equilibrium in acute hypoxia, revealing an extreme hypoxia tolerance. Experiments by Schofield and Chapman (2000) showed that Nile perch which is intolerant of low dissolved oxygen conditions initiated ASR when oxygen tension fell below $40 \mathrm{~mm} \mathrm{Hg}$ (approximately $3 \mathrm{mgl}^{-1}$ ). Nile perch gill ventilation rates increased with declining oxygen levels even after the initiation of ASR. For Nile perch, ASR may increase oxygen availability but not to a degree necessary to permit a lower gill ventilation rate like in other species. Work with cichlids showed a decrease in gill ventilation rates with the onset of ASR (Chapman et al., 1995). It is likely that the improvement of oxygen uptake associated with respiration at the air-water interface permitted a lower gill ventilation rate in these species. 
One major physiological cost to ASR is the increased locomotor activity required for repeated surfacing and skimming (Kramer, 1987). ASR places fish at significantly greater risk from aerial predation by birds (Kramer et al., 1983). It has been demonstrated that if fish perceived a risk of predation they modulated the behavioral component of the ASR chemoreflex (Shingles et al., 2005). In Lake Victoria, Barbus neumayeri Fischer decreases the cost of ASR by having a more efficient oxygen-uptake method that reduces time at the surface and lower the threshold for ASR (Olowo \& Chapman, 1996). Shingles et al. (2005) found that exposure of flathead grey mullet to a model avian predator delayed the onset of ASR in hypoxia or in response to direct chemoreceptor stimulation with Sodium cyanide $(\mathrm{NaCN})$. Additionally, the fish surfaced preferentially under a sheltered area in their experimental chamber or close to the walls. Thus, the behavioral component of the ASR reflex is plastic; it can be modulated by inputs from higher centers, in particular as a function of perceived risk of predation. A number of studies have demonstrated decreased spontaneous activities such as; feeding rate, metabolism, and/or predator activity under hypoxic stress (Breitburg et al., 1994; 2009; Ripley \& Foran, 2006). In this state, the risk of predation by piscivores may be reduced for fish prey; however, other aquatic predators may still take advantage of the negative effects of hypoxia on the ability of fish to escape (Domenici et al., 2007), thus shifting the balance towards a new player in the game.

\subsection{Air-breathing}

Fish breathing air use many structures to take up oxygen directly from air and some are able to switch from water to air breathing according to dissolved oxygen availability (Graham, 1997; Ilves \& Randall, 2007). Just as in ASR, air-breathing is considered a behavioral response to hypoxia. A number of bony fishes have evolved bimodal respiration, retaining functional gills but can also gulp air at the water surface and store this in an air-breathing organ $(\mathrm{ABO})$. The prevailing opinion is that hypoxia was the essential driving force for its evolution, and that it evolved from pre-existing ASR and bubble-holding behaviors (Graham, 1997; Graham and Lee, 2004). The primary benefit of air-breathing is that it makes oxygen uptake and aerobic metabolism entirely independent of the prevailing water oxygen availability (Graham, 1997). This enables fish to colonize extremely hypoxic regions. Persistence of a few relict species of phylogenetically ancient primitive bony and lobe-finned fishes, such as the lungfishes, is due in part to their ability to breathe air (Ilves \& Randall, 2007).

Air-breathing in theory, is more energetically efficient than water-breathing for fishes, because air is richer in oxygen and requires much less effort to ventilate (Kramer, 1983, 1987; Graham, 1997). For example, only one species of obligatory air-breathing fish, the lungfish, is known from the Lake Victoria basin. The rarity of air-breathing fishes in habitats with low DO may suggest there must be significant costs to air breathing (Kramer, 1983, 1987). These costs may include increased vulnerability to aerial predation and increased energetic costs of travel to the surface (Kramer, 1983; Kramer et al., 1983; Randle and Chapman, 2004). Airbreathing could also interfere with social interactions if fish were dependent upon constant visits to the surface. Kramer et al. (1983) used a trained heron to evaluate the risk of aerial predation for air-breathing fishes and non-air breathing fishes that use ASR in response to hypoxic stress. They found that fish using ASR tended to surface at lower DO thresholds than air breathers, though surfacing time was longer. They suggested that fish using ASR may incur less risk of avian predation at moderate DO levels, but air breathers seem to have 
an advantage under extreme hypoxia. Fish have also been shown to reduce the risk of surfacing by selecting less risky habitats or at less risky times of the diel cycle (Shingles et al., 2005).

\subsection{Haemoglobin switching}

Fish that are exposed to short-term hypoxia normally react with increased ventilation, reduction of external activity, and increased aquatic surface respiration (Van den Thillart GEEJM \& Van Waarde, 1985). When given time to adapt to the new environment, metabolic rates usually decrease resulting in higher hypoxia tolerance and reduced standard metabolic rate (Van den Thillart GEEJM et al. 1994). Many fish species adapt to hypoxia by reducing their metabolic rate and increasing hemoglobin oxygen $\left(\mathrm{Hb}-\mathrm{O}_{2}\right)$ affinity. Pilot studies with young broods of cichlids showed that the young, when gradually acclimatized, could survive severe hypoxia in contrast with the adults. It was therefore hypothesized that early exposure results in improved oxygen transport. Rutjes et al., (2007) using split experiments, broods of A. alluaudi, Haplochromis ishmaeli Boulenger, and a tilapia hybrid (Oreochromis) were raised either under normoxia (NR; $80-90 \%$ air saturation) or hypoxia (HR; $10 \%$ air saturation). The activity of the mitochondrial citrate synthase was not different between NR and HR tilapia, but was significantly decreased in HR A. alluaudi and H. ishmaeli, indicating lowered maximum aerobic capacities. On the other hand, hemoglobin and hematocrit levels were significantly higher in all HR fish of the three species, reflecting a physiological adaptation to safeguard oxygen transport capacity. In HR tilapia, intraerythrocytic GTP levels were decreased, suggesting an adaptive increase of blood- $\mathrm{O}_{2}$ affinity. Similar changes were not found in HR H. ishmaeli. In this species, however, all HR specimens exhibited a distinctly different iso-Hb pattern compared with their NR siblings, which correlated with a higher intrinsic $\mathrm{Hb}-\mathrm{O}_{2}$ affinity in the former. All $\mathrm{HR}$ cichlids thus reveal left-shifted $\mathrm{Hb}-\mathrm{O}_{2}$ equilibrium curves, mediated by either decreased allosteric interaction or, in $\mathrm{H}$. ishmaeli, by the production of new haemoglobins. They concluded that the adaptation to lifelong hypoxia is mainly due to improved oxygen transport. Some species like B. neumayeri survived extreme hypoxic conditions in the wetlands by combination of low metabolism, high haemoglobin, and very efficient use of aquatic surface respiration (Chapman \& Liem, 1995; Olowo \& Chapman, 1996; Chapman et al., 1999).

\section{Effects of hypoxia on activity}

\subsection{Parental care}

A significant metabolic cost for some fish species is the energy directed to parental care (Chapman \& McKenzie, 2009). Fishes that exhibit post-fertilization care have strategies ranging from simple nest guarding, to mouth brooding, to live bearing to ensure survival of their future generation (Fryer \& Iles, 1972). Several oviparous fishes in Lake Victoria protect their developing young after spawning by selecting suitable nesting sites, as well as nest building and guarding the young, fanning to aerate eggs, and mouthing to clean and remove dead and diseased eggs (Wootton, 1990). In mouth-brooding tilapias and haplochromines, the parents protect the young from predators and other environmental stressors such as low dissolved oxygen by moving to more suitable microhabitats (Trewavas 1983; Chapman et al., 2002). The costs to the parent associated with carrying the young 
include high energetic costs of bearing the young and increased predation risk due to reduced mobility (Timmerman \& Chapman, 2003). Nest-guarding fishes such as T. zillii use fanning to increase ambient oxygen levels around their eggs.

In mouth-brooders, the costs of parental care may be severe under hypoxia because of the increased requirements of oxygenating eggs when the parent cannot eat, and the elevated predation risks associated with any surfacing behavior. Nonetheless, high levels of parental care may be necessary under hypoxic conditions to ensure survival of the eggs and young. Wen-Chi Corrie et al., (2007) quantified the behavioral response to progressive hypoxia of the widespread mouth-brooding African cichlid, P. multicolor victoriae. This species responded to progressive hypoxia by performing ASR; however, brooding females showed higher ASR thresholds than males, and initiated ASR at a much higher threshold. Nonbrooding females did not differ from males for any ASR threshold. A high ASR threshold in brooding females may reflect various costs such as churning behavior, which is used to move the brood inside the mouth, potentially enhancing ventilation and cleaning of the eggs and young (Keenleyside, 1991). This may add to the energy expenditure of the female, particularly under hypoxic conditions.

\subsection{Social interactions}

When hypoxia elicits behaviors such as ASR or air breathing it increases the risk of predation, impacts on mobility of prey, and alters the dynamics of schooling behavior. Spacing within schools allows fish to keep track of one another without colliding. Domenici et al., (2002) suggested that the fast sound pulses emitted by some fishes, which may assist in synchronous response to predators may be less effective when school volume is increased under hypoxic stress. Hypoxia may also affect sensory channels involved in fish maneuverability, and thus impair fast anti-predator manoeuvres (Domenici et al., 2007). The use of ASR in response to extreme hypoxia has been demonstrated to affect social behaviors within groups of conspecifics. For example, in their study of ASR in swamp-dwelling and open-water populations of the haplochromine cichlid Astatotilapia "wrought-iron," Melnychuk and Chapman (2002) found that the pre-ASR aggression rate was higher in swamp-dwelling "wrought-iron" than in the open-water populations, but the aggression rate dropped in both open-water and swamp-dwelling fish between the pre-ASR and postASR periods. The use of ASR may impose both time and energetic constraints that reduce aggression. This could affect the development and maintenance of dominance hierarchies in cichlids and other species with complex social systems.

\subsection{Swimming activity}

Changes in spontaneous swimming activity have been described in a wide variety of fish groups and species when exposed to hypoxia. Behavioral responses can comprise either a reduction in activity or an increase in activity, depending upon the species and the context (Chapman \& McKenzie, 2009). It has been suggested that species that reduce their activity in hypoxia tend to be demersal or bentho/pelagic, with a relatively sedentary lifestyle during which they may often encounter hypoxia in their habitat; whereas species that increase activity tend to be active pelagic schooling fishes (Domenici et al., 2000). Swimming is typically considered to represent a major component of the energy budget of active fishes, 
and high-intensity aerobic swimming can utilize a very significant proportion of a fish's aerobic metabolic scope (Claireaux and Lefranc, ois, 2007). Thus, for those species that reduce levels of spontaneous swimming activity in hypoxia, this has been interpreted as an energy-saving response.

\section{Morphological changes}

\subsection{Gill structure}

The adaptive responses in fish in environments with increased hypoxia include an enlargement of the respiratory surface area (Chapman et al., 2000; Wanink \& Witte, 2000; Rutjes et al., 2007; Witte et al., 2008). A larger surface area allows for a more efficient oxygen transfer (Chapman et al., 2000). Studies of morphophysiological adaptations to hypoxic conditions in haplochromine cichlids from the Lake Victoria basin have indicated that a larger gill surface area is a common response to hypoxia both within and among species (Galis \& Barel, 1980; Hoogerhoud et al., 1983; Chapman et al., 2000). Offspring of adult $H$. pyrrhocepalus raised in hypoxia $\left(0.8 \mathrm{mg} \mathrm{O}_{2} \mathrm{l}^{-1}\right)$ gill surface area was $80 \%$ larger than that of their full sibs raised under normoxia $\left(6 \mathrm{mg} \mathrm{O}_{2} \mathrm{l}^{-1}\right)$ (Rutjes, 2006). Chapman et al. (2000) reported $18 \%$ difference in gill surface between $P$. multicolor victoriae reared in hypoxia (1.0 $\mathrm{mg} \mathrm{O}_{2} \mathrm{l}^{-1}$ ) and normoxia-reared sibs, and a difference of $29 \%$ for geographically isolated natural populations from a hypoxic $\left(0.4-3.8 \mathrm{mg} \mathrm{O}_{2} \mathrm{l}^{-1}\right)$ and a well-oxygenated habitat $(6.1 \mathrm{mg}$ $\left.\mathrm{O}_{2}{ }^{-1}\right)$. Similar increase in gill size was found in mormyrids Gnathonemus victoriae (Worthington), and P. catostoma from dense hypoxic swamp refugia near Lake Nabugabo compared to populations from well-oxygenated waters of nearby lakes (Chapman \& Chapman, 1998). The increase in gill surface area may be an adaptive response to hypoxic stress that has facilitated use of deep swamp refugia and permitted persistence with Nile perch in the Nabugabo system.

When $R$. argentea shifted towards a more benthic habitat an increase in the number of gill filaments and a decrease in the number of gill rakers was noticed. Wanink and Witte (2000) found the number of gill filaments on the first gill arch in $R$. argentea, to have increased by $3.6 \%$ between 1983 and1988. The increased gill size was postulated to have improved the capacity of R.argentea to extract oxygen from the water which had less oxygen than the previous habitat. Paterson and Chapman (2010) found significantly larger gills in Nile perch caught in wetland than in open-water habitats of Lake Nabugabo in 1996 and 2007. The larger gill size in wetland specimens could be used to extract oxygen in waters with lower DO levels. Witte et al., (2008) provided more direct evidence for rapid morphological changes in the Lake Victoria region by comparing archived specimens of an endemic haplochromine (Haplochromis (Yssichromis) pyrrhocephalus Witte \& Witte-Maas) to contemporary conspecifics. The zooplanktivorous $H$. pyrrhocephalus nearly vanished coincident with the upsurge of Nile perch in the 1980s, but recovered in the 1990s. The authors reported a total gill surface area of $64 \%$ greater in recently collected specimens (1993-2001) than in conspecifics collected prior to the Nile perch explosion (1977-1981). Further, Hoogerhoud et al., (1983) found a 1.6 times increase in gill size in Haplochromis (Gaurochromis) iris Hoogerhoud \& Witte, compared to closely related H. (G.) hiatus. During the rainy season, stratification and low DO (2-3 $\left.\mathrm{mgl}^{-1}\right)$ were occasionally observed in the deeper habitat (8-15m) of H. iris (Van Oijen et al., 1981). The capacity for plastic changes in 
all these species was to provide an adaptive response to fluctuations in environmental conditions especially pertaining to levels of DO.

\subsection{Head size}

Heads of fish are densely packed with muscles, bones, and other structures that are necessary for respiration, vision, feeding, and other functions. As a consequence of limited space, an increase in gill size may cause spatial conflicts with surrounding structures (Chapman et al., 2000). Consequently there is need for internal reorganization and change in head shape to create more space (Chapman et al., 2000). Chapman et al. (2000) found that hypoxia-reared $P$. multicolor victoriae had a greater head size than their normoxic sibs. They attributed enlarged head size to an increase in space necessary for the larger gill apparatus. Head length, and total head volume were notably smaller in wild caught modern $H$. pyrrhocephalus that experienced increased hypoxia. Total gill surface in the resurgent $H$. pyrrhocephalus increased by $64 \%$ (Witte et al., 2008). Plasticity experiments with $H$. pyrrhocephalus from the pre-Nile perch period resulted in an increase of $9.4 \%$ in head volume of hypoxia-reared fish (Rutjes, 2006). Bouton et al., (2002a) studied the head shape of a number of closely-related haplochromine species from four rocky islands with water ranging from murky with low DO levels $\left(3.8 \mathrm{mg} \mathrm{l}^{-1}\right)$ to clear with high DO levels $\left(5.1 \mathrm{mg} \mathrm{l}^{-1}\right)$ in Lake Victoria. Of eight environmental variables, oxygen was the most important factor influencing head shape. Fish from sites with high DO had small narrow opercular compartment (containing the gills) compared to those from locations with low DO.

\section{Phenotypic plasticity and evolution}

Phenotypic plasticity (PP) an environmentally induced change in the phenotype is frequently discussed in relation to speciation (Chapman et al., 2000; Bouton et al., 2002b). Low oxygen availability has led to evolution of varied morphological and physiological plasticity in fishes, including development of breathing organs, increased gill size, modification in blood carrying capacity, and change in metabolism. Phenotypic plasticity due to hypoxia may increase the probability of fish to colonize, survive, and reproduce in changing or new environments, probably resulting in genetic change through assimilation (West-Eberhard, 1989). In addition, strong selection pressure for hypoxia tolerance may lead to geographical variation among populations. Air breathing and the ultimate evolution of terrestrial vertebrates is thought to have been an evolutionary response to low atmospheric and dissolved oxygen concentrations during the Devonian period (Clack, 2007). Several studies have documented phenotypic plasticity in the jaw, skull, gill size and body shape of fishes (Wanink \& Witte, 2000; Chapman et al., 2000; Bouton et al., 2002b). There are suggestions that environmentally induced phenotypic variation can be selectively advantageous and can contribute to the origin of new traits (Bouton et al., 2002).

Resurging populations in Lake Victoria are encountering a changed environment compared to the one they lived in earlier on. It is therefore logical to expect the new fauna to differ in composition and ecosystem function from the previous. Species that shifted to hypoxic wetland refugia in response to predation by Nile perch or those that are recovering in the currently hypoxic areas of Lake Victoria have potentially experienced strong selection pressure for low oxygen tolerance over multiple generations. For these species, changes have been found in respect to gill size, body shape, and respiratory physiology (Wanink \& 
Witte, 2000; Witte et al., 2008). However, it is not fully known whether these changes are the result of a heritable response to selection or phenotypic plasticity, or both. Nonetheless, over several generations of strong selection pressure in hypoxic refugia it is possible that heritable changes among these characters may occur. This may lead to geographical variation between hypoxia dwelling populations and those in high DO regions, particularly in traits related to oxygen uptake.

This is particularly possible in haplochromine cichlids of Lake Victoria which are wellknown for their rapid evolution and adaptive morphological radiation. More than 500 endemic species evolved within the geologically short period of $100000-400000$ years. Phenotypic plasticity was documented in the feeding apparatus, in gills and in eye structures (Chapman et al., 2000; Bouton et al., 2002b; Rutjes, 2006). For example, the recovery of $H$. pyrrhocephalus the most common haplochromine in Mwanza Gulf encountered greatly changed environmental conditions (Witte et al., 2008). In the 1970s, DO levels in its habitat was rarely below $3 \mathrm{mgl}-1$, while after recovery in the mid-1980s the same habitat often had DO even below $1 \mathrm{mgl}^{-1}$ (Wanink et al., 2001). In response to the hypoxic conditions, there were changes in gill, head and eye sizes. The morphological changes over a time span of only two decades could be the combined result of phenotypic plasticity and genetic change and may have fostered recovery of this species (Witte et al., 2008). According to Chapman et al., (2000) the difference in P. multicolor victoriae gill size in hypoxia and welloxygenated habitat may be the result of a combination of inherited changes and phenotypic plasticity. Similarly, the observed interdemic variation in the gill morphology of $B$. neumayeri may be due to underlying genetic differences (Chapman et al., 1999). However, environmentally induced phenotypic plasticity and/or the interaction of genetic and environmental influences may also contribute to the observed differences in gill size.

The change in external body shape may have consequences on fish locomotory performance and competitiveness on the new individuals. Chapman et al. (2008) found significant differences in the streamline and trophic morphology of $P$. multicolor victoriae that correspond to intraspecific differences in gill size. Such morphological changes may limit the survival success of phenotypes in new habitats. Alternatively, genetic exchange among cichlids may greatly be limited because they depend on choice of mates that look phenotipically like themselves. Similarly, the large difference in gill size among the swamp and open water dwelling $B$. neumayeri has a morphological cost to swamp-dwelling which may affect competitive abilities for those that move into an open water system (Chapman et al., 1999).

Taxonomists have been cautioned on reliance on morphological characters difference in species differentiation of the old and modern populations of haplochromines cichlids (Van Oijen, 1991; Witte et al., 2008). The fast responses may reflect environmentally driven phenotypic plasticity and/or canalized genetic change, in addition to the possibility of introgression through hybridization (Streelman et al., 2004). They recommend future studies to combine methods such molecular genetics, morphometrics and colour among others in differentiation of species.

\section{Conclusion}

The future status of hypoxia in Lake Victoria and its consequences for fish will depend on a combination of anthropogenic factors and climate change. Human population pressure will 
likely continue to be the main driving factor in the eutrophication and subsequent hypoxia in the lake. Expanding population and agriculture for food will result in increased nutrient loading and increased eutrophication into the lake. Global warming, increased water temperatures, and precipitation may make the lake more susceptible to development of hypoxia through direct effects on stratification, solubility of oxygen, increased organism metabolism, and remineralization rates. Large changes in rainfall patterns are also predicted (International Panel on Climate Change [IPCC], 2007). If these changes in rainfall lead to increased runoff to Lake Victoria, stratification and nutrient loads are likely to increase and worsen oxygen depletion. Equally, if stratification decreases due to lower runoff or is disrupted by increased storm activity or intensity, the chances for oxygen depletion should decrease.

Increasing and widespread deep-water anoxia in Lake Victoria might put at risk the entire fishery (Kaufman, 1992). Increasing hypoxia could lead to further changes in species composition, population decline, fish kills, and creation of widespread "dead zones," as has happened in the Gulf of Mexico and Lake Erie (Pollock et al., 2007). In Lake Victoria, such changes could have a catastrophic effect on millions of people who are economically dependent on the lake for their livelihood. It is therefore imperative to understand the consequences of hypoxia and its effect on the fisheries. To adequately manage the lake, an understanding of natural and anthropogenic factors leading to anoxia need to be fully understood. For immediate solutions, land practices or conditions that indirectly enhance deoxygenation in the lake need to be identified to underpin water quality management. Eutrophication and associated impacts of hypoxia in Lake Victoria, may be reversed if effective nutrient management is instituted. The same has happened in eutrophic lakes following a rigorous nutritive management system (Jeppesen et al., 2005). A management system which allows a heavy, but sustainable, Nile perch fishery, may allow the coexistence of many indigenous species. There are remnant populations of fishes in the lake basin in refugias such as satellite lakes that may act as potential sources for seeds for resurgence (Kaufman \& Ochumba, 1993; Seehausen et al., 1997; Balirwa et al., 2003). With proper management which integrates sustainability and conservation, it might be possible to restore Lake Victoria faunal near to its original one.

\section{References}

Akiyama, T., Kajumulo, A.A. \& Olsen, S. (1977). Seasonal variations of plankton and physicochemical condition in Mwanza Gulf, Lake Victoria. Bulletin of Freshwater Fisheries Research Laboratory, 27, 49-61.

Balirwa, J., C. A. Chapman, L.J. Chapman, K. Geheb, R. Lowe-McConnell, O. Seehausen, J. Wanink, R. Welcomme, and F. Witte (2003). The role of conservation in biodiversity and fisheries sustainability in the Lake Victoria Basin. In Lake Victoria 2000: A New Beginning. Bioscience 53 (8), 703-715.

Bouton N, de Visser J, Barel C.D.N. (2002a). Correlating head shape with ecological variables in rock-dwelling haplochromines (Teleostei: Cichlidae) from Lake Victoria. Biological Journal of the Linnean Society 76, 39-48

Bouton N, Witte, F., \& Van Alphen J.J.M. (2002b). Experimental evidence for adaptive phenotypic plasticity in a rock-dwelling cichlid fish from Lake Victoria. Biological Journal of the Linnean Society 77, 185-192 
Breitburg, D. L., Steinberg, N., DuBeau, S., Cooksey, C., \& Houde, E.D. (1994). Effects of low dissolved oxygen on predation on estuarine fish larvae. Mar Ecol Prog Ser 104, 235 246.

Breitburg, D. L., Hondorp, D. W., Davias, L. W., \& Diaz, R. J. (2009). Hypoxia, nitrogen and fisheries: Integrating effects across local and global landscapes. Ann Revs Mar Sci 1, 329-349.

Calamari D., Akech M.O. \& Ochumba P.B.O. (1995) Pollution of Winam Gulf, Lake Victoria, Kenya: A study case for preliminary ris assessment. Lakes and Reservoirs: Research and Management 1, 89-106

Chapman, L.J. \& Liem, K.F. (1995). Papyrus swamps and the respiratory ecology of Barbus neumayeri. Environmental Biology of Fishes 44,183-197.

Chapman, L.J., Kaufman, L.S., Chapman, C.A., \& McKenzie, F.E. (1995). Hypoxia tolerance in twelve species of East African cichlids: Potential for low oxygen refugia in Lake Victoria. Conservation Biology, 9, 1274-1288.

Chapman, L.J., Chapman, C.A., Ogutu-Ohwayo, R., Chandler, M., Kaufman, L., \& Keiter, A. (1996). Refugia for endangered fishes from an introduced predator in Lake Nabugabo, Uganda. Conservation Biology 10, 554-561.

Chapman, L.J. \& C.A. Chapman. (1998). Hypoxia tolerance of the mormyrid Petrocephalus catostoma: Implications for persistence in swamp refugia. Copeia 1998, 762-768.

Chapman, L.J., Chapman, C.A., \& Crisman, T.L. (1998). Limnological observations of a papyrus swamp in Uganda: Implications for fish faunal structure and diversity. Verhandlungen Internationale Vereinigung Limnologie 26, 1821-1826.

Chapman, L.J., Chapman, C.A., Brazeau, D., McGlaughlin, B., \& Jordan, M. (1999). Papyrus swamps and faunal diversification: Geographical variation among populations of the African cyprinid Barbus neumayeri. Journal of Fish Biology 54,310-327.

Chapman, L.J., Galis, F. \& Shinn, J. (2000). Phenotypic plasticity and the possible role of genetic assimilation, Hypoxia-induced trade-offs in the morphological traits of an African cichlid. Ecol Lett, 3, 387-393.

Chapman, L.J., Chapman, C.A., Nordlie, F.G., \&. Rosenberger, A.E. (2002). Physiological refugia: Swamps, hypoxia tolerance, and maintenance of fish biodiversity in the Lake Victoria Region. Comparative Biochemistry and Physiology 133 (A),421-437.

Chapman, L.J., Chapman, C.A, Schofield, P.M., Olowo, J.P., Ole Seehausen L. \& OgutuOhwayo, R. (2003). Fish faunal resurgence in Lake Nabugabo, East Africa Conserv Biol, 17(2), 500-511.

Chapman, L.J., Albert, J., \& Galis, F. (2008) Developmental plasticity, genetic differentiation, and hypoxia-induced trade-offs in an African cichlid fish. Open Evolution Journal 2, 75-88.

Chapman, L.J. \& McKenzie, D. (2009). Behavioral responses and ecological consequences. In: Fish Physiology. Hypoxia. Vol. 27, J.G. Richards, A.P. Farrell, \& C.J. Brauner eds, pp. 26-77. Elsevier, Academic Press, San Diego, CA.

Clack, J.A. (2007). Devonian climate change, breathing, and the origin of the tetrapod stem group. Integrated Comparative Biology 47, 510-523. 
Claireaux, G., \& Lefranc,ois, C. (2007). Linking environmental variability and fish performance: Integration through the concept of scope for activity. Phil Trans R Soc B 362, 2031-2042.

Crul, R.C.M. (1995). Limnology and hydrology of Lake Victoria. Verhandlungen Internationale Vereinigung Limnologie, 25, 39-48.

Diaz, R.J. \& Breitburg, D.L. (2009). The hypoxic environment. In: Fish Physiology. Hypoxia. Vol. 27. J.G. Richards, A.P. Farrell, \& C.J. Brauner eds, pp. 1-23. Elsevier, Academic Press, San Diego, CA.

Domenici, P., SteVensen, J. F., \& Batty, R.S. (2000). The effect of progressive hypoxia on swimming activity and schooling in Atlantic herring. Journal of Fish Biology 57, 1526-1538.

Domenici, P., Ferrari, R. S., Steffensen, J. F., \& Batty, R. S. (2002). The effects of progressive hypoxia on school structure and dynamics in Atlantic herring Clupea harengus. Proceedings of Royal Society B, 269, 2103-2111.

Domenici, P., Lefranc,ois, C., and Shingles, A. (2007). Hypoxia and the anti-predator behaviour of fishes. Phil. Trans. R. Soc. B. 362, 2105-2121.

Farrell, A.P. \& Richards J.G. (2009). Defining hypoxia: an integrative synthesis of the responses of fish to hypoxia. In: Fish Physiology. Hypoxia. Vol. 27. J.G. Richards, A.P. Farrell, \& C.J. Brauner eds, pp. 482-503. Elsevier, Academic Press, San Diego, CA.

Fish, G.R. (1956). Some aspects of the respiration of sex species of fish from Uganda. Journal of Experimental Biology. 33, 186-195.

Fryer, G., \& Iles, T.D. (1972). "The Cichlid Fishes of the Great Lakes of Africa: Their Biology and Evolution." Oliver and Boyd, London

Galis, F. \& Barel, C.D.N. (1980). Comparative functional morphology of the gills of African lacustrine Cichlidae (Pisces, Teleostei), An ecomorphological approach. Netherlands Journal of Zoology, 30, 392-430

Graham, J.B. (1990). Ecological, evolutionary, and physical factors influencing aquatic animal respiration. Am Zoo. 30, 137-146.

Graham, J.B. (1997). "Air Breathing Fishes: Evolution, Diversity, and Adaptation" Academic Press, San Diego.

Graham, J.B., \& Lee, H.J. (2004). Breathing air in air: In what ways might extant amphibious fish biology relate to prevailing concepts about early tetrapods, the evolution of vertebrate air breathing, and the vertebrate land transition? Physiol. Biochem. Zool. 77, 720-731.

Goudswaard, K.P.C , Wanink, J.H., Witte, F., Katunzi E.F.B., Berger, M.R. \& Postma D.J. (2004). Diel vertical migration of major fish-species in Lake Victoria, East Africa. Hydrobiologia 513, 141-152.

Goldschmidt, T., Witte, F. \& Wanink, J. (1993). Cascading effects of the introduced Nile perch on the detritivorous: phytoplanktivorous species in the sublittoral areas of Lake Victoria. Conservation Biology, 7, 686-700.

Hecky, R.E., Bugenyi, F.W.B., Ochumba, P., Talling, J.F., Mugidde R., Gophen M. \& Kaufman L. (1994). Deoxygenation of the deep water of Lake Victoria, East Africa. Limnologya and Oceanograpy, 39 (6), (1476-1481). 
Hoogerhoud, R. J. C., Witte, F. and Barel, C. D.N. (1983). The ecological differentiation of two closely resembling Haplochromis species from Lake Victoria $(H$. iris and $H$. hiatus; Pisces, Cichlidae). Netherlands Journal of Zoology 33, 283-305.

Ilves, K.L., \& Randall, D.J. (2007). Why have primitive fishes survived? In: Primitive Fishes. Fish Physiology Vol. 26, D.J. McKenzie, C.J. Brauner \& A. P. Farrell, Eds., Fish Physiology, pp. 516-536. Academic Press, Elsevier, San Diego, CA.

IPCC, International Panel on Climate Change (2007). “Climate Change 2007: The Physical Science Basis." Cambridge University Press, New York.

Jeppesen, E., Søndergaard, M., Jensen, J. P., Havens, K. E., Anneville, O., Carvalho, L., Coveney, M. F., Deneke, R., Dokulil, M. T., Foy, B., Gerdeaux, D., Hampton, S. E., et al. (2005). Lake responses to reduced nutrient loading: an analysis of contemporary long-term data from 35 case studies. Freshwater Biology 50, 1747-1771.

Kaufman, L.S. (1992). Catastrophic change in species-rich freshwater ecosystems: The lessons of Lake Victoria. Bioscience, 42, 846-858.

Kaufman, L.S. \& Ochumba, P.B.O. (1993). Evolutionary and conservation biology of cichlid fishes as revealed by faunal remnants in northern Lake Victoria. Conserv Biol, 7, 719-730.

Kaufman, L.S., Chapman, L.J. \& Chapman, C.A. (1997). Evolution in fast forward: Haplochromine fishes of the Lake Victoria region. Endeavour, 21, (23-30).

Keenleyside, M.H.A. (1991). Parental care. In: Cichlid Fishes: Behaviour, Ecology and Evolution. M.H.A Keenleyside, Ed. Chapman and Hall, New York.

Kudhogania, A.W. \& Cordone, A.J. (1974). Batho-spatial distribution pattern and biomass estimation of the major demersal fishes in Lake Victoria. African Journal of Hydrobiology and Fisheries 3, 15-31.

Kramer, D.J. (1983). The evolutionary ecology of respiratory mode in fishes: an analysis of on costs of breathing. Environment Biology Fish, 9, (145-158).

Kramer D.J., Manley, D. \& Bourgeois, R. (1983). The effect of respiratory mode and oxygen concentration of the risk of aerial predation in fishes. Canadian Journal Zoology 61, 653-665.

Kramer, D.J. (1987). Dissolved oxygen and fish behaviour. Environment Biology Fish, 18, 8192.

Ligtvoet, W. \& Mkumbo, O. C. (1990). Synopsis of ecological and fishery research on Nile perch (Lates niloticus) in Lake Victoria, conducted by HEST/TAFIRI, 35-74. In: CIFA, Report of the fifth session of the sub-committee for the development and management of the fisheries in Lake Victoria, 12-14 Sept. 1989, Mwanza, Tanzania. FAO Fish. Rep. 430, FAO. Rome.

Ligtvoet W., Mous P.J., Mkumbo, O.C., Budeba, Y.L., Goudswaard, P.C., Katunzi, E.F.B., Temu, M.M., Wanink, J.H. \& Witte, F. (1995). The Lake Victoria fish stocks and fisheries. In: Fish Stocks and Fisheries of Lake Victoria: A handbook for field observations. F. Witte \& L.T. van Densen, eds, pp. 11-53, Samara Publishing Limited, Netherlands.

Lung'ayia H.B.O., M’Harzi, A., Tackx, M., Gichuki, J. \& Symoens, J.J. (2000). Phytoplankton community structure and environment in the Kenyan waters of Lake Victoria. Freshwater Biology 43, 529-43. 
Maithya, J. (1998). A survey of the Itchthyofauna of Lake Kanyaboli and other small water bodies in Kenya: Alternative refugia for endangered fish species. NAGA. ICLARM, Quartely 3, 54-56.

Mkumbo O.C. \& Ligtvoet W. (1992) Changes in the diet of Nile perch, Lates niloticus (L.) in Mwanza Gulf, Lake Victoria. Hydrobiologia 232, 79-83.

Mugidde, R., Gichuki, J., Rutagemwa, D., Ndawula, L., \& Matovu, A. (2005). Status of water quality and its implication on fishery production, In: The state of the fisheries resources of Lake Victoria and their management pp106-112. Poceedings of the regional stakeholders' conference. Entebe, Uganda- LVFO, Jinja, Uganda. ISBN 9970-713-1012

McKenzie, D.J., Hale, M., \& Domenici, P. (2007). Locomotion in primitive fishes. In: Primitive Fishes. Fish Physiology, Vol. 26, D.J. McKenzie, C.J. Brauner \& A.P. Farrell Eds.,pp. 162-224. Academic Press, Elsevier, San Diego, CA.

Melnychuk, M.C. \& Chapman, L.J. (2002). Hypoxia tolerance of two haplochromine cichlids: Swamp leakage and potential for interlacustrine dispersal. Environmental Biology of Fishes 65, 99-110.

Miranda, L.E., Driscoll, M.P. \& Allen, M.S. (2000). Transient physico-chemical micro-habitats facilitate fish survival in inhospitable aquatic plants stands. Freshwater Biology 44, 617-28.

Njiru, M., Othina, A., Getabu, A., Tweddle, D. \& Cowx I.G. (2002). "The invasion of water hyacinth, Eichhornia crassipes Solms (Mart.), a blessing to Lake Victoria fisheries". In: Management and Ecology of Lake and Resevoirs Fisheries, I. G. Cowx Ed, pp 255-263, Fishing News Books, Blackwell Science, Oxford, UK.

Njiru M., Okeyo-Owour, J.B., Muchiri M. \& Cowx, I.G. (2004). Shift in feeding ecology of Nile tilapia in Lake Victoria, Kenya. African. Africa Journal off Ecology 42, (163-170).

Njiru, M., Waithaka, E., Muchiri, M., van Knaap, M. \& Cowx, I.G. (2005). Exotic introductions to the fishery of Lake Victoria: What are the management options? Lakes and Reservoirs: Research and Management 10, 147-155.

Ochumba P.B.O. (1990). Massiv fish kills within the Nyanza Gulf to Lake Victoria, Kenya. Hydrobiologia 208, 93-99.

Olowo, J.P. \& Chapman, L.J. (1996). Papyrus swamps and variation in the respiratory behaviour of the African fish Barbus neumayeri. African Journal of Ecology 34, 211222.

Ogutu-Ohwayo, R. (1990). The decline of the native fishes of lakes Victoria and Kyoga (East Africa) and the impact of introduced species, especially the Nile perch, Lates niloticus and the Nile tilapia, Oreochroms niloticus. Environmental Biology of Fishes 27, 81-96.

Ogutu-Ohwayo, R. (1994). Adjustments in fish stocks and in life history characteristics of the Nile perch, Lates niloticus L. in lakes Victoria, Kyoga and Nabugabo. Ph.D thesis. University of Manitoba. 213 p.

Paterson, J.A. \& Chapman, L.J. (2010). Intraspecific variation in gill morphology of juvenile Nile perch, Lates niloticus, in Lake Nabugabo, Uganda. Environmental Biology of Fishes 88,97-104 DOI: 10.1007/s10641-010-9600-6. 
Perry, S.F. \& McDonald, G. (1993). Gas exchange. In: The Physiology of Fishes, D. H. Evans ed., pp. 251-78. CRC Press, Boca Raton, USA.

Pollock, M.S.,Clarke, L.M.J. \& Dube M.G. (2007). The effects of hypoxia on fishes: from ecological relevance to physiological effects. Environment Reviews 15, 1-14.

Randle, A.R. \& Chapman, L.J. (2004). Habitat use by the air-breathing fish Ctenopoma muriei: Implications for costs of breathing. Ecology of Freshwater Fish 13, 37-45.

Reardon, E.E. \& Chapman, L.J. (2010). Energetics of hypoxia in a mouth-brooding Cichlid: Evidence for interdemic and developmental effects. Physiological and Biochemical Zoology 83(3), 414-423. DOI: 10.1086/651100

Riedmiller, S. (1994). Lake Victoria fisheries: the Kenyan reality and environmental implications. Environmental Biology of Fishes. 39, 329-338.

Rutjes, H.A. (2006). Phenotypic responses to lifelong hypoxia in cichlids Ph.D., Dissertation, Leiden University, Netherlands.

Rutjes, H.A., Nieveen, M.C., Weber, R.E., Witte, F., \& van den Thillart, G.E.E.J.M.. (2007). Multiple strategies of Lake Victoria cichlids to cope with lifelong hypoxia include haemoglobin switching. American Journal of Physiology 293, 1376-1383.

Ripley, J.L., and Foran, C.M. (2006). Influence of estuarine hypoxia on feeding and sound production by two sympatric pipefish species (Syngnathidae). Marine Environment Research 63, 350-367.

Rosenberger, A.E. \& Chapman, L.J. (1999). Hypoxic wetland tributaries as faunal refugia from an introduced predator. Ecology of Freshwater Fish 8, 22-34.

Rosenberger, A.E. \& Chapman, L.J. (2000). Respiratory characters of three haplochromine cichlids: Implications for persistence in wetland refugia. Journal of Fish Biology 57, 483-501.

Seehausen O., Witte, F., Katunzi, E.F., Smits, J. \& Bouton, N. (1997). Patterns of the remnant cichlid fauna in southern Lake Victoria. Conservation Biology, 11, 890-904.

Schofield, P.J. \& Chapman, L.J. (2000). Hypoxia tolerance of introduced Nile perch: Implications for survival of indigenous fishes in the Lake Victoria Basin. African Zoology 35, 35-42.

Shingles, A., McKenzie, D.J., Claireaux, G., \& Domenici, P. (2005). Reflex cardioventilatory responses to hypoxia in the flathead grey mullet (Mugil cephalus) and their behavioural modulation by perceived threat of predation and water turbidity. Physiol. Biochem. Zool. 78, 744-755.

Streelman, J.T., Gmyreck, S.L., Kidd, M.R., Kidd, C., Robinson, R.L., Hert, E., Ambali, A.J., \& Kocher, T.D. (2004). Hybridization and contemporary evolution in an introduced cichlid fish from Lake Malawi national park. Molecular Ecology 13, 2471-2479.

Talling, J.F. (1966). The annual cycle of stratification and phy- toplankton growth in Lake Victoria (East Africa). Int. Rev. Gesamten Hydrobiol. 51, 545-621.

Timmerman, C.M. \& Chapman, L.J. (2003). The effect of gestational state on oxygen consumption and response to hypoxia in the sailfin molly (Poecilia latipinna). Environmental Biology of Fishes 68, 293-299.

Trewavas, E. (1983). Tilapiine species of the Genera Sarotherodon, Oreochromis and Danakila. London British Museum (Natural History) Publication No. 583. 
Twongo, T.F., Bugenyi, F.W. \& Warda, F. (1995). The potential for further proliferation of water hyacinth in Lake Victoria, Kyoga and Kwania and some urgent aspects for research. African Journal of Tropical Hydrobiology and Fisheries 6, 1-10.

Van den Thillart, GEEJM., Dalla Via, J., Cattani, O., De Zwaan, A. (1994). Influence of longterm hypoxia exposure on the energy metabolism of Solea solea. I. Critical $\mathrm{O}_{2}$ levels for aerobic and anaerobic metabolism. Marine Ecology Progressive Series 104, 109117 ,

Van den Thillart, GEEJM, Van Waarde, A. (1985). Teleosts in hypoxia: aspects of anaerobic metabolism. Mol Physiol 8, 393-409.

Van Oijen, M.P.J., Witte F. \& Witte-Maas E.L.M. (1981). An introduction to ecological and taxonomic investigations on the haplochromine cichlids from the Mwanza Gulf of Lake Victoria. Netherlands Journal of Zoology 31, 149-174.

Van Oijen M.P.J. (1991). A systematic revision of the piscivorous haplochromine Cichlidae (Pisces, Teleostei) of Lake Victoria (East Africa). Part 1. Zoologische Verhandelingen 272, 1-95.

Verheyen, E., Blust, R. \& Decleir W. (1986). Hemoglobin heterogeneity and the oxygen affinity of hemolysate of some Victoria cichlids. Comprative Biochemistry and Physiology 84(A), 315-318

Verschuren, D., Johnson, T.C., Kling, H. J., Edgington, D.N., Leavitt P.R., Brown E.T., Talbot M.R. \& Hecky R.E. (2002). History and timing of human impact on Lake Victoria, East Africa, 7 Proceedings of Royal Society London, B 269, 289-294. DOI 10.1098/ rspb. 2001. 1850

Stager, J.C. \& Johnson, T.C. (2007). The late Pleistocene desiccation of Lake Victoria and the origin of its endemic biota. Hydrobiologia 596: doi:10.1007/210750-007-9158-2.

Wanink, J.H. \& Witte, F. (2000). Rapid morphological changes following niche shift in the zooplanktivorous cyprinid Rastrineobola argentea from Lake Victoria. Netherlands Journal of Zoology 50 (3), 365-372.

Wanink, J.H, Kashindye, J.J, Goudswaard, P.C., Witte, F. (2001). Dwelling at the oxycline: does increased stratification provide a predation refugium for the Lake Victoria sardine Rastrineobola argentea? Freshwater Biology 46, 75-85.

Wen-Chi Corrie, L., Chapman, L.J. \& Reardon, E. (2007). Brood protection at a cost: Mouthbrooding under hypoxia in an African cichlid. Environmental Biology of Fishes 82, 41-49.

West-Eberhard M.J. (1989). Phenotypic plasticity and theorigins of diversity. Annual Review of Ecology and Systematics 20, 249-278.

Wetzel, R.G. (2001). "Limnology. Lakes and Rivers Ecosystems." Academic Press, San Diego.

Witte, F., Goldschmidt ,T., Goudswaard, P.C., Ligtvoet, W., Van Oijen, M.J.P. \& Wanink, J.H. (1992a). Species extinction and concomitant ecological changes in Lake Victoria. Netherlands Journal of Zoology, 42, 214-232.

Witte, F., Goldschmidt, T., Wanink, J., Van Oijen, M., Goudswaard, K., Witte-Maas, E. \& Bouton, N. (1992b). The destruction of an endemic species flock: quantitative data on the decline of the haplochromine cichlids of Lake Victoria. Environmental Biology of Fishes, 34, 1-28. 
Witte, F., Msuku, B.S, Wanink, J.H., Seehausen, O., Katunzi, E.F.B., Goudswaard, P.C., Goldschmidt, T. (2000). Recovery of cichlid species in Lake Victoria: an examination of factors leading to differential extinction. Rev Fish Biol Fish 10, 233241.

Witte, F., Wanink, J.H. \& Kishe-Machumu, M. (2007). Species distinction and the biodiversity crisis in Lake Victoria. Transaction of the American Fisheries Society, 136, 1146-1159.

Witte, F., Welten, M., Heemskerk, M., van der Stap I, Ham, L., Rutjes, H. \& Wanink, J. (2008) Major morphological changes in a Lake Victoria cichlid fish within two decades. The Linnean Society of London, Biological Journal of the Linnean Society, 94, (41-52).

Wootton, R. J. (1990). "Ecology of Teleost Fishes." Chapman and Hall, New York.

Worthington, E.B. (1930). Observations on the temperature, hydrogen-ion concentration, and other physical conditions of the Victoria and Albert Nyanzas. Inter Rev Ges Hydrobiol, 24, 328-357. 


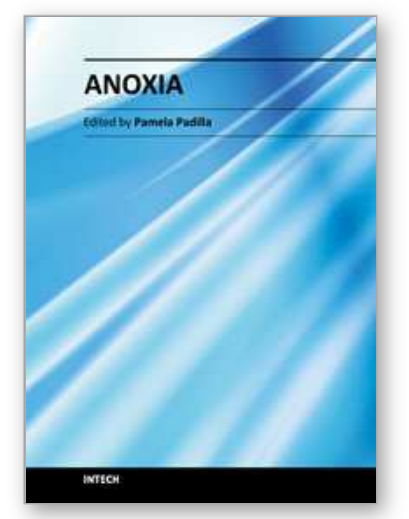

\author{
Anoxia \\ Edited by Dr. Pamela Padilla
}

ISBN 978-953-307-664-5

Hard cover, 146 pages

Publisher InTech

Published online 05, January, 2012

Published in print edition January, 2012

This book reviews how severe oxygen deprivation affects biological systems - from the molecular to the ecological level. The contributing authors come from diverse regions of the world, which proves the interest in the academic analysis of oxygen deprivation. The diversity in the experimental approach scientists take, in order to understand the influence oxygen deprivation has on living systems, is apparent throughout this book. One of the presented ideas deals with the exploration and examination of the physiological, cellular and genetic characteristics of killifish embryos and nematodes exposed to anoxia. Furthermore, the book includes material on the mechanisms regulating hypoxia and anoxia tolerance and their implications of on human health issues. Finally, new methodologies to examine oxygen deprivation and the impact of human-related activities on oxygen level, within important ecological systems such as Lake Victoria, are presented. There is no doubt that the oxygen molecule is central to every stratum of biological systems.

\title{
How to reference
}

In order to correctly reference this scholarly work, feel free to copy and paste the following:

Murithi Njiru, Chrisphine Nyamweya, John Gichuki, Rose Mugidde, Oliva Mkumbo and Frans Witte (2012). Increase in Anoxia in Lake Victoria and Its Effects on the Fishery, Anoxia, Dr. Pamela Padilla (Ed.), ISBN: 978953-307-664-5, InTech, Available from: http://www.intechopen.com/books/anoxia/increase-in-anoxia-in-lakevictoria-and-its-effects-on-the-fishery

\section{INTECH}

open science | open minds

\section{InTech Europe}

University Campus STeP Ri

Slavka Krautzeka 83/A

51000 Rijeka, Croatia

Phone: +385 (51) 770447

Fax: +385 (51) 686166

www.intechopen.com

\section{InTech China}

Unit 405, Office Block, Hotel Equatorial Shanghai

No.65, Yan An Road (West), Shanghai, 200040, China 中国上海市延安西路65号上海国际贵都大饭店办公楼405单元

Phone: +86-21-62489820

Fax: $+86-21-62489821$ 